Pavements Research Program

\title{
Environmental Evaluation of Dust Stabilizer Products
}

Jeffery Steevens, Burton Suedel, Alfreda Gibson, Alan Kennedy,

August 2007

William Blackburn, David Splichal, and J. Thomas Pierce 


\section{Environmental Evaluation of Dust Stabilizer Products}

Jeffery Steevens, Burton Suedel, Alfreda Gibson, Alan Kennedy, William Blackburn, and David Splichal

Environmental Laboratory

U.S. Army Engineer Research and Development Center 3909 Halls Ferry Road

Vicksburg, MS 39180-6199

J. Thomas Pierce

Navy Environmental Health Center

620 JP Jones Circle \#1100

Portsmouth, VA 23708

Final report

Approved for public release; distribution is unlimited. 


\begin{abstract}
Personnel of the U.S. Army Engineer Research and Development Center (ERDC), Vicksburg, MS, and Navy Environmental Health Center (NEHC), Portsmouth, VA, evaluated the environmental fate and effects of six commercially available dust stabilizer products. As part of the evaluation, a relative risk comparison was made of the six materials to other materials that have been used historically to control dusts (i.e., diesel, crude oil, fuel oil). Data for this evaluation were obtained primarily through literature review, communication with the manufacturers of the products, and through some limited analytical chemistry. Data gaps and uncertainties were also identified and described. Conclusions were derived from the results of the evaluation, with each stabilizer group presented separately along with general conclusions applicable to all stabilizers studied.
\end{abstract}

DISCLAIMER: The contents of this report are not to be used for advertising, publication, or promotional purposes. Citation of trade names does not constitute an official endorsement or approval of the use of such commercial products. All product names and trademarks cited are the property of their respective owners. The findings of this report are not to be construed as an official Department of the Army position unless so designated by other authorized documents. 


\section{Contents}

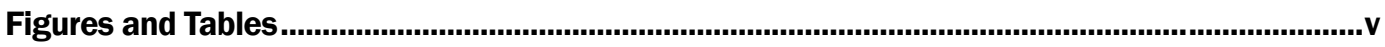

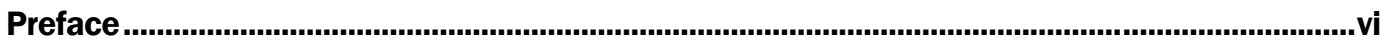

Executive Summary .....................................................................................................................................vii

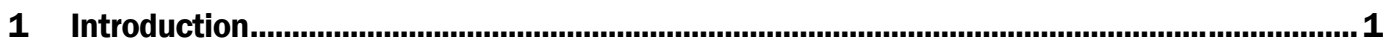

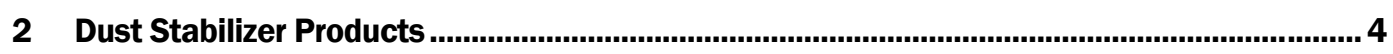

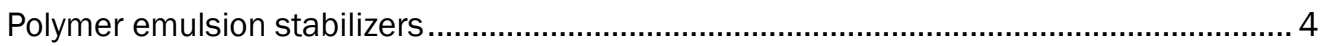

Formulation, use, and properties...................................................................................... 4

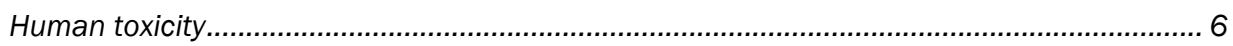

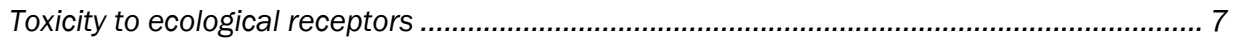

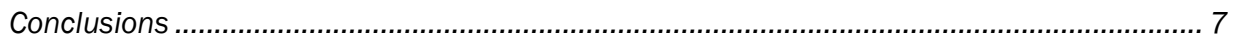

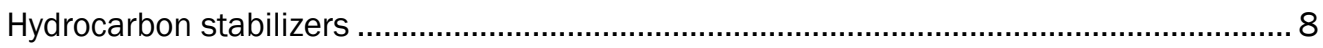

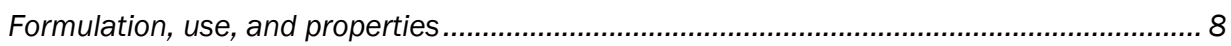

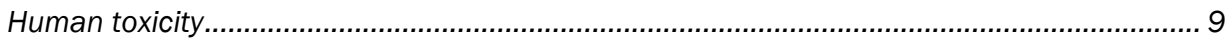

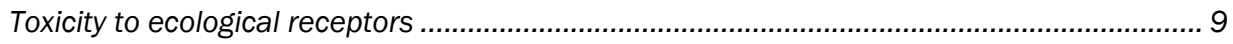

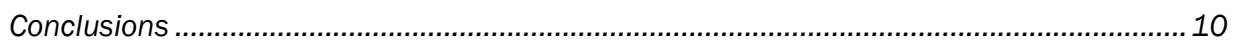

Polysaccharide stabilizers ................................................................................... 10

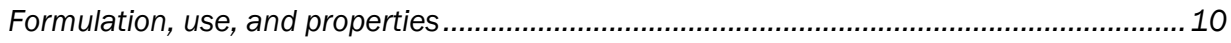

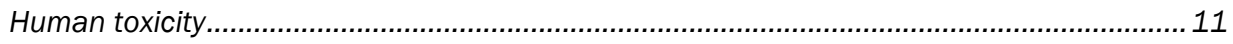

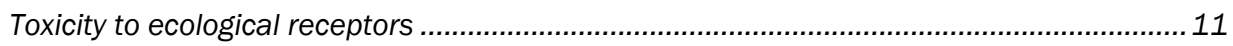

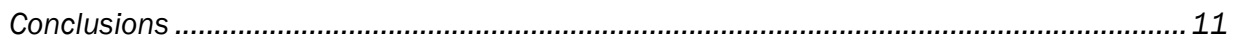

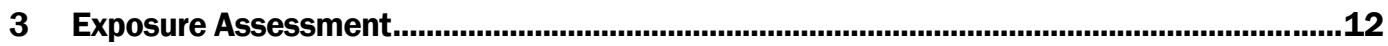

Identification and evaluation of receptor populations and exposure pathways .................12

Potential releases to and transport in the environment ....................................................12

Potential exposure pathways for humans ........................................................................ 13

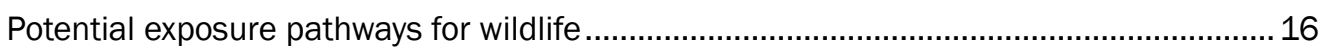

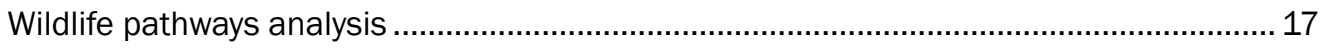

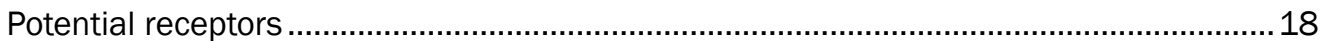

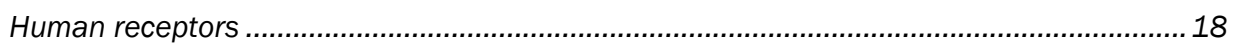

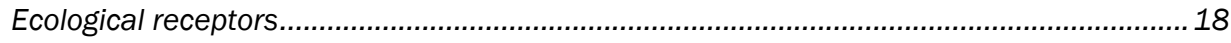

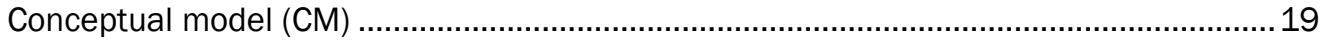

4 Comparative Risk

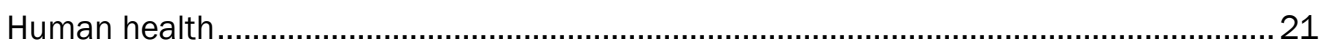

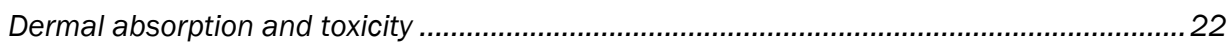

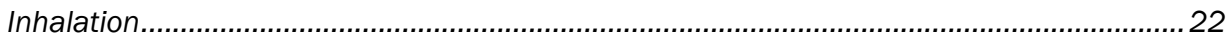

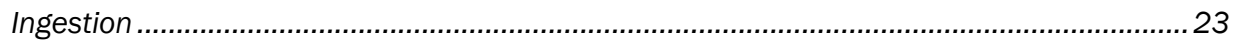

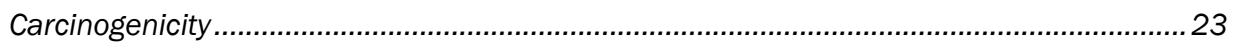

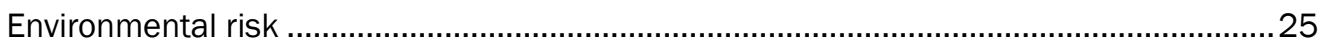




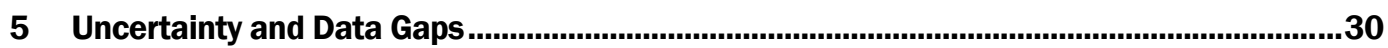

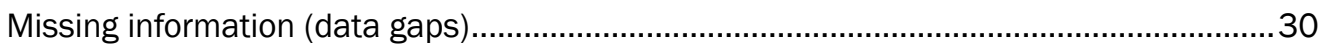

Errors in the conceptual model .................................................................................. 30

Use of representative species ................................................................................ 31

6 Conclusions............................................................................................................................32

Vinyl acetate and acrylic polymer dust stabilizers........................................................... 32

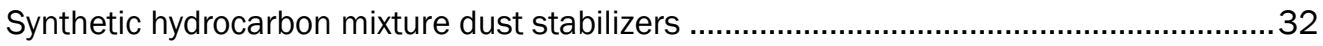

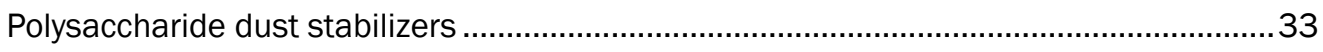

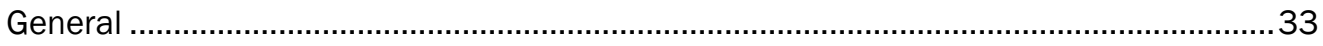

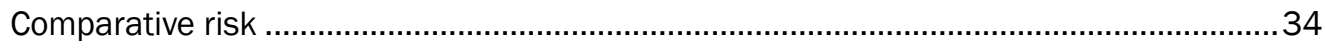

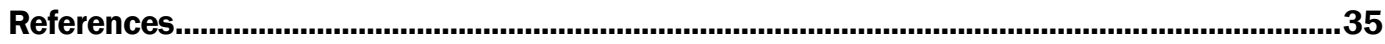

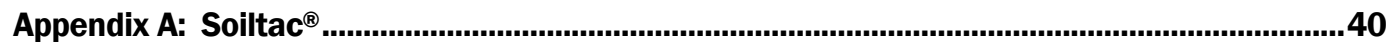

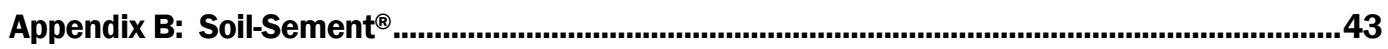

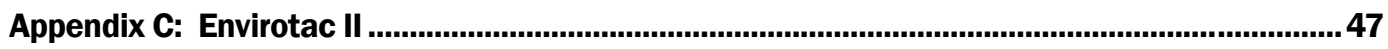

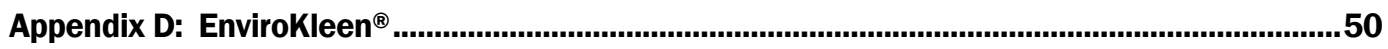

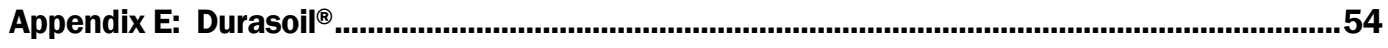

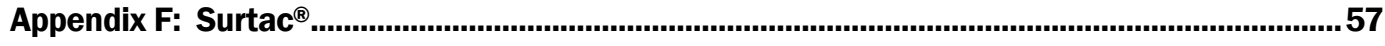

\section{Report Documentation Page}




\section{Figures and Tables}

\section{Figures}

Figure 1. Conceptual model for human and ecological receptors potentially exposed to soil stabilizers.

Figure 2. Graphical summary of median lethal concentrations inducing 50 percent lethality $\left(\mathrm{LC}_{50}\right)$ for historically used petroleum and more recently formulated soil stabilizer products.

\section{Tables}

Table 1. Manufacturer and ERDC-GSL recommended application rates for dust stabilizers............. 4

Table 2. Inhalation exposure limits and reference exposure calculations..........................................23

Table 3. Cancer classification of dust stabilizers and relevant materials......................................... 24 


\section{Preface}

This report was prepared as part of the Pavements Research Program, AT22 Work Package 238, for the Assistant Secretary of the Army for Acquisition, Logistics, and Technology, to describe a risk-based assessment of the human health and environmental impacts of six commercially available dust stabilizers.

Users of information from this report include the U.S. military's engineer units charged with expedient road and airfield construction, the U.S. Army Maneuver Support Battle Lab, U.S. Army Engineer School, U.S. Army Force Projection Battle Lab Support Element, U.S. Army Deployment Modernization Office, U.S. Army Force Projection Center of Excellence, U.S. Army Force Projection Program Manager, U.S. Transportation Command, U.S. Army Corps of Engineers, Airfield Commanders, U.S. Army Aeronautical Services Agency, U.S. Air Force Civil Engineer Support Agency, U.S. Air Force Air Mobility Command, and agencies assigned operations planning responsibilities.

This report was prepared by personnel from the U.S. Army Engineer Research and Development Center (ERDC), Environmental Laboratory (EL), Vicksburg, MS, and U.S. Navy Environmental Health Center (NEHC), Portsmouth, VA. The findings and recommendations presented in this report are based upon tests and analyses conducted at ERDC. The research team consisted of Dr. J effery Steevens, Dr. Burton Suedel, Dr. Sandra Brasfield, Alan Kennedy, Leslie Yoo, Alfreda Gibson, William Blackburn, and Richard A. Price, Environmental Risk Assessment Branch, EL; Christina Kennedy, Environmental Processes Branch, EL; and Dr. J . Thomas Pierce, NEHC. This report was prepared under the supervision of Dr. Robert P. J ones, Acting Chief, Environmental Risk Assessment Branch, EL; Dr. Richard E. Price, Chief, Environmental Processes and Engineering Division; and Dr. Beth Fleming, Director, EL.

COL Richard B. J enkins was Commander and Executive Director of ERDC. Dr. J ames R. Houston was Director. 


\section{Executive Summary}

Personnel of the U.S. Army Engineer Research and Development Center (ERDC), Vicksburg, MS, and Navy Environmental Health Center (NEHC), Portsmouth, VA, evaluated the environmental fate and effects of six commercially available dust stabilizer products. As part of the evaluation, a relative risk comparison was made of the six materials to other materials that have been used historically to control dusts (i.e., diesel, crude oil, fuel oil). Data for this evaluation were obtained primarily through literature review, communication with the manufacturers of the products, and through some limited analytical chemistry. Data gaps and uncertainties were also identified and described. Conclusions were derived from the results of the evaluation, with each stabilizer group presented separately along with general conclusions applicable to all stabilizers studied.

\section{Vinyl Acetate and Acrylic Polymer Dust Stabilizers}

- Vinyl acetate and acrylic polymers are stable in soils after curing and are unlikely to be available to terrestrial organisms or be transported in runoff water. The limited mammalian data suggest the polymer is relatively non-toxic. If present, the vinyl acetate fraction is a potential carcinogen. When used in large volumes, potential exposure may occur during handling and application. Precautions should be taken to limit exposure during preparation, application, and cleanup.

- The ecotoxicological data are limited to aquatic studies with uncured polymer and represent a worst-case scenario for materials reaching aquatic receptors. Because the exact formulation composition for the polymer is unknown it is difficult to estimate environmental risk parameters used to determine fate and transport.

- Data gaps for these stabilizers include degradation information, terrestrial toxicity, and potential for polymer to result in inhalation exposures.

\section{Synthetic Hydrocarbon Mixture Dust Stabilizers}

- Envirokleen ${ }^{\circledR}$ and Durasoil ${ }^{\circledR}$ are mixtures of synthetic hydrocarbon compounds with little or no toxicity to humans or ecological receptors. 
- Their hydrophobicity indicates that they are likely to sorb to soils and sediments and be relatively stable in these environments and therefore unlikely to be transported in water.

- Hydrocarbon-based stabilizers may cause some limited toxicity in sediments as a result of ingestion of sediment particles with sorbed product.

- Data gaps for these stabilizers include degradation information, terrestrial toxicity, and potential for polymer to result in inhalation exposures.

\section{Polysaccharide Dust Stabilizers}

- The main ingredients of Surtac ${ }^{\circledR}$ are sugar, starch, and soap and are thus expected to pose little or no environmental hazards.

- No data exist regarding the environmental fate and transport as well as human health and ecotoxicological properties.

\section{General}

- The exposure assessment indicated that applicators and the war fighter can potentially come into contact with dust stabilizers. Persons in these groups can most likely contact stabilizers via direct contact with the material or through incidental ingestion of soil, dermal contact, and inhalation of airborne particles.

- Ecological receptors most likely to contact stabilizers are those that are immobile or have limited mobility such as plants and soil invertebrates, respectively. In arid environments, species such as lizards could contact stabilizer-treated soils. In addition, organisms that burrow may be exposed through inhalation of volatile compounds or particles derived from the dust stabilizers. Stabilizers that are water soluble can be mobilized via surface runoff and reach nearby water bodies where aquatic and benthic receptors can contact these materials. Stabilizers that are insoluble may be transported in runoff water through the transport of product sorbed to soil and sediment particles.

- A comparison between petroleum stabilizers and the nontraditional stabilizers clearly showed the stabilizer products in the current evaluation are much less toxic to aquatic organisms than the petroleum products used historically by the DoD. The acute aquatic $\mathrm{LC}_{50}$ values for unleaded gasoline, diesel fuel, lube oil, Kuwait crude and Prudhoe Bay crude generally ranged from 1 to $300 \mathrm{mg} / \mathrm{L}$, which are considered to be slightly to moderately toxic. Conversely, the five commercially 
available stabilizers for which data were available indicated $\mathrm{LC}_{50}$ values ranging from a low of $500 \mathrm{mg} / \mathrm{L}$ up to $>10,000 \mathrm{mg} / \mathrm{L}$, indicating that these products are considered practically nontoxic to relatively harmless as defined by the U.S. Fish and Wildlife Service (1984).

- There is a lack of aquatic toxicity data available for all the products studied. While the relative toxicity of five of the six subject stabilizers were in the practically nontoxic to relatively harmless range, it is unclear whether the lack of aquatic toxicity based on unpublished manufacturers data holds true for other species. Confirmatory studies are needed to determine the toxicity with more certainty and document these effects.

- There is a need to determine the toxicity of these products to other species such as plants, soil invertebrates, and reptiles that can reasonably contact these products in the field.

\section{Comparative Risk}

- Comparing human health risks across various dust suppression agents, the bio-derived products such as the polysaccharide stabilizers exhibit much lower toxicity. Thus, the hierarchy of controls can be less strict than for synthetic molecules used in dust stabilizer formulations containing vinyl acetate, acrylic acid and hydrocarbons.

- For vinyl acetate, acrylic, and hydrocarbon dust stabilizers, extensive respiratory and dermal protection is necessary during formulation and typically during applications. Demonstration projects may show that there are no, or limited emissions, suggesting the exposure will not occur thus eliminating the potential risk.

- The vinyl acetate and acrylic polymers Soiltac ${ }^{\circledR}$, Soil-Sement ${ }^{\circledR}$, and Envirotac II ${ }^{\circledR}$, the hydrocarbon compound mixtures Envirokleen ${ }^{\circledR}$ and Durasoil ${ }^{\circledR}$, and the polysaccharide compound Surtac ${ }^{\circledR}$ all appear to be relatively nontoxic to the environment. 


\section{Introduction}

Dust stabilizers (also called dust suppressants or palliatives) are chemicals or other materials used to control airborne dust from land surfaces. They work by changing the physical and chemical properties of the soil surface. Dust stabilizers are used to meet air quality standards, control nuisance dust, and reduce erosion of soils. Specific applications include mining, construction, agriculture, and military activities (Sanders and Addo 1993; U.S. Environmental Protection Agency (USEPA) 2004). Dust control during military activities is a critical need due to increased training and operations in arid environments.

A wide variety of soil stabilizer chemicals and other materials have been used for dust abatement (Gebhart et al. 1996; Price et al. 1991; USEPA 2004). Materials used for dust abatement include fresh and saltwater, salts and brines (e.g., calcium chloride and magnesium chloride), petroleum-based organics (e.g., asphalt emulsions, crude oil, and diesel fuel), non-petroleum-based organics (e.g., vegetable oils, molasses, and ligninsulfonate), mulch and fiber mixtures (e.g., lignin products), clay additives (e.g., bentonite and montmorillonite), electrochemical products (e.g., ammonium chloride and enzymes), and synthetic polymers (e.g., polyvinyl acetate and vinyl acrylic) (Sanders and Addo 1993; Bolander and Yamada 1999; USEPA 2004).

Depending on type, dust stabilizers work in one of three ways, all of which basically transform smaller dust particles into bigger particles (Bolander and Yamada 1999; Lohnes and Coree 2002; Tingle et al. 2004; USEPA 2004). Salts, brines, and clay additives attract moisture to soil particles. Water, petroleum-based products, and some synthetic organic materials form a crust or protective surface on the soil. Many of the synthetic polymer products and non-petroleum products act as a binding agent to agglomerate or aggregate soil particles. Electrochemical materials expel water from soil voids, thus increasing soil compaction.

Dust stabilizers are typically diluted in water at the site and applied to the soil surface by spraying suppressant directly to the surface via a spray hose, gun, or bar at the rear of a truck (USEPA 2004). The type of application used depends on the acreage needing coverage. Stabilizer benefits 
are maximized when sufficient soil penetration is achieved, usually on the order of 10-20 mm thickness (Bolander and Yamada 1999).

Most of the research concerning dust stabilizers has focused on the effectiveness with which these stabilizers bind and sequester soil particles (Sanders and Addo 1993; Epps and Ehsan 2002; Tingle et al. 2004; USEPA 2004). Little is known regarding the fate and potential human and environmental effects associated with application and use of these products for dust control. The majority of the environmental studies published to date have focused on salts and brines, ligninsulfonates, and petroleum-based products (Roald 1977; Zhordania et al. 1982; Ettinger 1987; Heffner 1997; Kimball 1997; Lohnes and Coree 2002; USEPA 2004).

Non-petroleum based organics, especially ligninsulfonate and salts such as calcium chloride, are the most widely used dust stabilizers in the United States (Lohnes and Coree 2002; Washington Department of Ecology 2003). In Washington state, ligninsulfonate products were used in 41 percent of dust abatement road projects, followed by water (33 percent), magnesium chloride (8 percent), emulsified asphalt (8 percent), petroleum products and calcium chloride (both at 4 percent), and other products at 2 percent (Washington Department of Ecology 2003). However, human health, environmental, and other concerns over the use of many of these materials preclude their use for military activities, especially in arid environments. For example, salts and brines have corrosive properties (Bolander and Yamada 1999; Addo et al. 2004) thus posing a maintenance problem and precluding their use around military vehicles. Salts are also toxic to some species of trees and other vegetation (Bolander and Yamada 1999) and work best in areas where the relative humidity is above 30-40 percent (Hefner 1997), precluding their use in arid environments. Ligninsulfonate is highly water soluble, causing erosion and leaching of the lignin during exposure to moisture, thus resulting in strength degradation (Palmer et al. 1995, as reported in Tingle et al. 2004). This susceptibility to moisture precludes its use in many military applications. The scarcity of water in arid areas of the world precludes its use in these environments. Thus, there is a need for materials that are readily available in large quantities that can be transported to remote regions of the world to suppress dust during military activities. These materials must also not be hazardous to human health or the environment. For these reasons, alternatives to the more commonly used salts, ligninsulfonates, and petroleum products (e.g., crude oil) such as synthetic polymers and polysaccharides are receiving increased interest by the Department of 
Defense (DoD) and others for use in remote arid regions of the world. However, synthetic polymers usually consist of proprietary materials, and thus their fate and effects on human health and the environment are poorly understood (Rauch et al. 2003).

The purpose of this report is to provide a risk-based approach assessing the human health and environmental impacts of select dust stabilizers. The U.S. Army Engineer Research and Development Center (ERDC), Geotechnical and Structures Laboratory (GSL), is exploring the application of stabilizers to control dusts associated with military activities. Several of these stabilizers have shown efficacy in dust control in field trials (Rushing et al. 2005, 2006; Tingle et al. 2004; Gebhart et al. 1996) and are candidates for many DoD applications. These stabilizer additives are EnviroKleen ${ }^{\circledR}$, Durasoil ${ }^{\circledR}$, Soil-Sement ${ }^{\circledR}$, Soiltac ${ }^{\circledR}$, Envirotac II ${ }^{\circledR}$, and Surtac $^{\circledR}$.

The objectives of this research are to (1) summarize existing physical and chemical properties, fate and transport, and effects information on the subject materials; (2) identify risk exposure pathways; (3) estimate parameters used to calculate risk; and (4) provide recommendations regarding potential hazards. The approach used in this report employs the hazard identification process to develop a conceptual model and outline likely exposure pathways and ecological and human receptors as part of dust stabilizer use. The potential risk associated with label application use of these products is summarized and conclusions made regarding the potential effects of each stabilizer. 


\section{Dust Stabilizer Products}

Three categories of dust stabilizers are evaluated in this report. A total of six stabilizers were considered. The categories and specific stabilizer compounds evaluated include:

- Polymer Emulsions. Soiltac ${ }^{\circledR}$ (Appendix A), Soil-Sement ${ }^{\circledR}$ (Appendix B), and Envirotac II ${ }^{\circledR}$ (Appendix C) are polymer emulsion based stabilizers that contain vinyl acetate and/ or acrylic polymers

- Hydrocarbon-Based Synthetic Fluids. EnviroKleen ${ }^{\circledR}$ (Appendix D) and Durasoil ${ }^{\circledR}$ (Appendix E) are hydrocarbon mixtures

- Polysaccharide-Based Stabilizer. Surtac ${ }^{\circledR}$ (Appendix F) is a blend of polysaccharides, surfactants, and water.

Each stabilizer has different recommended application rates and preparation instructions for use in controlling dusts at helipads, airplane runways, and roadways (Table 1). For each class of stabilizer, a description of use, chemical and physical properties, fate and transport, and toxicology is outlined. In addition, data gaps identified in the evaluation of potential human health and environmental risk have been identified.

Table 1. Manufacturer and ERDC-GSL (Rushing et al. 2006) recommended application rates for dust stabilizers (gal/yd²).

\begin{tabular}{|l|l|l|l|l|l|l|l|}
\hline \multirow{2}{*}{ Product } & \multicolumn{9}{|l|}{ Manufacturer Application Rate, gal/yd ${ }^{2}$} & \multicolumn{2}{l|}{ GSL Rate, gal/yd ${ }^{2}$} \\
\cline { 2 - 8 } & Helipad & Runway & Roadway & Dilution & Helipad & Roadway & Dilution \\
\hline Soiltac & 0.257 & 0.257 & 0.15 & $1: 4,1: 4,1: 6$ & 1 & 0.8 & $1: 3$ \\
\hline Soil-Sement & 0.15 & 0.36 & 0.3 & $1: 9$ & 1 & 0.8 & $1: 3$ \\
\hline Envirotac II & 0.35 & 0.35 & 0.15 & $1: 4$ & 1 & 0.8 & $1: 3$ \\
\hline EnviroKleen & 0.36 & 0.225 & 0.45 & none & 0.36 & 0.8 & none \\
\hline Durasoil & 0.3 & 0.3 & 0.3 & none & 0.36 & 0.8 & none \\
\hline Surtac & 1 & - & - & $1: 3$ & 0.6 & NR & $1: 3$ \\
\hline
\end{tabular}

\section{Polymer emulsion stabilizers}

Formulation, use, and properties

Soiltac ${ }^{\circledR}$, Soil-Sement ${ }^{\circledR}$, and Envirotac II ${ }^{\circledR}$ are dust stabilizers that contain vinyl acetate polymers or acrylic polymers. The composition of the vinyl acetate polymers is primarily the polymer (Soiltac ${ }^{\circledR}$ is 50 - 65 percent and Soil-Sement ${ }^{\circledR}$ is 5- 50 percent polymer, respectively), water, and small 
quantities of vinyl acetate monomer ( $<0.5$ percent). Independent analysis at ERDC determined by gas chromatography mass spectrometry that Soiltac ${ }^{\circledR}$ contained $375 \mathrm{mg} / \mathrm{L}$ vinyl acetate. In contrast, vinyl acetate was not detected in Soil-Sement ${ }^{\circledR}$. The other polymer, Envirotac $\mathrm{II}^{\circledR}$, is composed of acrylic copolymer (39- 43 percent) and water (35- 50 percent).

The recommended application rates and uses are described in Table 1. As with all of the dust stabilizers, the recommended application rate varies widely and depends on physical characteristics of the soil, weather conditions (e.g., humidity), soil moisture levels, compaction, and presence and type of vehicular traffic. Dilution of the product is recommended prior to application and ranges from 1:4 to 1:9 parts product to water. Application rates of the diluted material for the polymer emulsions range from 0.15 to $0.36 \mathrm{gal} / \mathrm{yd}^{2}$. This translates into roughly 0.1 to $0.5 \mathrm{gal} / \mathrm{yd}^{2}$ of undiluted product applied to the soil surface. Recommended application rates from ERDC-GSL studies (Rushing et al. 2006) recommend higher rates of application ranging from 0.8 to $1.0 \mathrm{gal} / \mathrm{yd}^{2}$. After application, polymers are allowed to cure from 2 to 24 hours before traffic is allowed on the surface. Effective dust control resulting from the polymer stabilizers is reported to last from 12 to 24 months for topical applications. After which, a small amount of dust stabilizer can be reapplied for maintenance of dust reduction.

The non-polymerized components of these formulations have much different properties than the polymerized form. The vinyl acetate polymers contain relatively low levels of vinyl acetate. Vinyl acetate is relatively water soluble, has a half-life of around 7 days in the environment, and is rapidly degraded through hydrolysis. Therefore, the vinyl acetate component, while mobile, is unlikely to persist in substantive quantities. Other soluble constituents of the unpolymerized form are unknown.

Following application, the polymers coalesce, forming a layer of soilpolymer matrix on the surface of the soil. In this form, the materials are unlikely to be mobile in water and air and most likely will be bound up with soil and sediment particles as larger aggregates. Application of these polymers is reported to be effective for 1 to 2 years, suggesting their resilience to degradation. In the polymerized form, the half-life of the vinyl acetate and acrylic polymers in soil, sediment, or water is unknown. Little bioaccumulation of the polymer stabilizers is expected due to the size of the molecules and the inability of the product to cross membranes (Guiney et al. 1998). 


\section{Human toxicity}

The bioavailability of the cured vinyl acetate and acrylic polymers is expected to be below levels that can cause toxicity. The cured product is expected to have limited biological significance. However, there is some potential for effects associated with exposure to the unpolymerized formulation prior to application.

One of the constituents of the vinyl acetate polymer is vinyl acetate. A significant amount of data is available regarding the toxicity of vinyl acetate. As a substrate for polymerization, vinyl acetate is a concern due to its metabolism (e.g., more toxic products are actually produced through its biological transformation). The 2-carbon ethenyl group (like vinyl chloride) is metabolized by carboxyesterase to yield acetate and acetaldehyde. Acetaldehyde is suggested to be an initiator or possibly a promoter of nasal tumors (Hazardous Substance DataBank (HSDB) 2006). Thus, exposures occurring during its formulation or administration are a potential issue. There is evidence in rodents that vinyl acetate is a carcinogen, resulting in its classification as a 2B carcinogen. It is thought that the mechanism of toxicity is through direct DNA damage. Non-carcinogenic effects are rather limited. Chronic exposures suggest no effects at exposure levels below 5 to $10 \mathrm{ppm}$ in air. At higher exposure levels ( 7 to $142 \mathrm{ppm}$ ), effects include CNS perturbation, emphysema, early onset mortality, and changes in hepatic enzymes. Chronic exposure (100 weeks) to drinking water resulted in increased liver neoplasms and uterine adenocarcinomas. Several limits have been established for vinyl acetate (HSDB 2006). The American Council of Government Industrial Hygienists (ACGIH) has established two threshold limit values: a time-weighted average (TWA) of $10 \mathrm{ppm}$ in air for exposure during an 8-hr work day and short-term exposure limit (STEL) of $15 \mathrm{ppm}$ which represents the highest allowable level during a short-term exposure. The Occupational Safety and Health Administration (OSHA) has established Permissible Exposure Limits (PEL) of $10 \mathrm{ppm}$ (TWA) and $20 \mathrm{ppm}$ (STEL) for a 15-min exposure. The National Institute for Occupational Safety and Health (NIOSH) established a single standard of $4 \mathrm{ppm}$ for a 15-min exposure.

As a substrate for polymerization, acrylate is of concern due to dermatologic conditions, more specifically, common contact allergy. Structurally and toxicologically, vinyl acetate and acrylate share a two-carbon functionality. Like vinyl acetate, once reacted, the potential for human exposure or effects from acrylate-incorporating polymers is of limited significance. Acrylate polymers are considered relatively benign and 
physically non-reactive. Inhalation reference exposure concentrations should be kept below $200 \mathrm{mcg} / \mathrm{m}^{3}$ ( $\sim 50 \mathrm{ppb}$ ) (Pierce 2006). No standards have been developed by NIOSH, OSHA, or ACGIH for acrylate in this form.

\section{Toxicity to ecological receptors}

There is some variability in the range of aquatic toxicity values reported for SoilTac ${ }^{\circledR}$, Soil-Sement ${ }^{\circledR}$, and Envirotac II ${ }^{\circledR}$. No terrestrial toxicity data were found for any of the polymer-based products. Specific aquatic toxicity values reported in manufacturer's data reports and product information for each product are described below.

SoilTac ${ }^{\circledR}$ is relatively non-toxic to aquatic receptors. However, limited toxicity was reported in two aquatic invertebrates, Daphnia magna and Ceriodaphnia dubia. The $\mathrm{LC}_{50}$ values, which are the concentrations of chemicals lethal to 50 percent of the test organism popylation, for $\mathrm{D}$. magna and C. dubia were 608 and $154 \mathrm{mg} / \mathrm{L}$, respectively. Other toxicity data reported $\mathrm{LC}_{50}$ values greater than $1,000 \mathrm{mg} / \mathrm{L}$ for green algae and two species of fish: the rainbow trout and fathead minnow.

Soil-Sement ${ }^{\circledR}$ is reported to cause toxicity in rainbow trout but no toxicity in other aquatic organisms. In definitive toxicity assessments, $\mathrm{LC}_{50}$ values for rainbow trout in acute and chronic studies were $320 \mathrm{ml} / \mathrm{L}$ and $510 \mathrm{ml} / \mathrm{L}$, respectively. No toxicity was reported in the aquatic invertebrates Americamysis bahia or D. magna or the fathead minnow or goldfish at concentrations up to $1,000 \mathrm{mg} / \mathrm{L}$.

Only one study was found for Envirotac II ${ }^{\circledR}$. A study using fathead minnows reported no effect on survival at concentrations up to $750 \mathrm{mg} / \mathrm{L}$.

\section{Conclusions}

Overall, formulations that use vinyl acetate and acrylic polymers are stable in soils after curing. As a result, they are unlikely to be available to terrestrial organisms or be transported in runoff water. The limited mammalian data suggest the polymer is relatively non-toxic. However, the vinyl acetate fraction is a potential carcinogen. When used in large volumes, potential exposure may occur during handling and application. Therefore, precautions should be taken to limit exposure during preparation, application, and cleanup. The ecotoxicological data are limited to aquatic studies with uncured polymer. As a result, these studies represent a worst-case 
scenario of material reaching an aquatic receptor in the most unstable form. Because the exact formulation composition for the polymer is unknown, it is difficult to estimate environmental risk parameters used to determine fate and transport. Data gaps include degradation information, terrestrial toxicity, and potential for polymer to result in inhalation exposures.

\section{Hydrocarbon stabilizers}

\section{Formulation, use, and properties}

EnviroKleen ${ }^{\circledR}$ and Durasoil ${ }^{\circledR}$ are hydrocarbon-based synthetic dust stabilizers. They are composed of hydrotreated alkanes and ring compounds. Because the formulations are trade secrets, it is difficult to ascertain the exact chemical composition of these materials. Furthermore, chemical analysis is even more complicated because chemical analysis of these compounds yields a spectrum of analytes. Chemical analysis by ERDC using gas chromatography with flame ionization detection revealed a range of carbon peaks from C22 to C30 and C18 to C28 for Durasoil ${ }^{\circledR}$ and EnviroKleen ${ }^{\circledR}$, respectively. These peaks are very similar to those observed for petroleum distillates such as mineral oil. There were some detectable metals (Al, Fe, Mn, and Zn) in samples of Durasoil ${ }^{\circledR}$ (TSL 2002). However, these metals were in very low concentrations and likely an artifact of the storage container (steel drums).

EnviroKleen ${ }^{\circledR}$ and Durasoil ${ }^{\circledR}$ are recommended for a wide range of dust control uses. Dilution of the product is not recommended and therefore must be applied to the soil as provided by the manufacturer. Application rates for the synthetic hydrocarbon stabilizers range from 0.225 to $0.45 \mathrm{gal} / \mathrm{yd}^{2}$. Recommended application rates from ERDC studies range from 0.36 to $0.8 \mathrm{gal} / \mathrm{yd}^{2}$ (Rushing et al. 2006). After application, synthetic hydrocarbon formulations do not require time to cure, allowing traffic immediately after application. Application of the EnviroKleen ${ }^{\circledR}$ and Durasoil ${ }^{\circledR}$ lasts from 9-16 months and can be effective indefinitely when maintained.

Little to no environmental fate data were found for EnviroKleen ${ }^{\circledR}$ and Durasoil ${ }^{\circledR}$. However, both of these products are non-polar and have relatively low or negligible solubility in water. Therefore, neither compound is likely to be soluble or transported in groundwater or surface water. However, due to their hydrophobicity, they are more likely to become attached to soil particles and be transported to water in overland flow during ero- 
sion processes (NRC 2003). There is very little information regarding the potential for either compound to degrade in soils or water. However, hydrocarbon compounds are susceptible to biotic and photo-induced degradation (Hatzinger and Alexander 1995). In a single study using the Organisation for Economic Co-operation and Development (OECD) method 301B, EnviroKleen ${ }^{\circledR}$ was incubated with activate sludge for 35 days. At the end of the 35-day incubation period, nearly 60 percent of the material had degraded (Midwest Industrial Supply 2001). In addition to biotic degradation, there is also the potential for photodegradation for most hydrocarbon-based organic compounds, such as the ring structures in Durasoil ${ }^{\circledR}$. Because of the wide range of degradation rates for hydrocarbon compounds, it is difficult to predict the half-life of these materials in soils or sediments. Product literature states that Durasoil ${ }^{\circledR}$ has an effective life span of 9 to 16 months, suggesting limited potential for degradation.

\section{Human toxicity}

The hydrocarbon stabilizers are referred to by their manufacturer as severely hydro-treated paraffinic hydrocarbons. The toxicological significance of this term is of limited importance. Hydrocarbons produce anesthetic, if not narcotic, effects in high concentrations. They are also often flammable and can produce dermatitis. Inhalation reference exposure concentrations should be kept below $200 \mathrm{mcg} / \mathrm{m}^{3}$ (Pierce 2006).

\section{Toxicity to ecological receptors}

According to manufacturer's data, EnviroKleen ${ }^{\circledR}$ and Durasoil ${ }^{\circledR}$ were nontoxic to five aquatic species including rainbow trout, fathead minnow, mysid shrimp, green algae, Microtox ${ }^{\circledR}$ marine bacteria, and water flea (C. dubia) in acute and chronic toxicity tests at concentrations up to 1,000 to $10,000 \mathrm{mg} / \mathrm{L}$. Aquatic toxicity was also observed in two species, the amphipod (Hyalella azteca) and the water flea (D. magna). In preliminary studies, significant mortality in D. magna was observed at concentrations as low as $1 \mathrm{mg} / \mathrm{L}$ Durasoil ${ }^{\circledR}$ (BES 2005c). In more definitive studies, the $\mathrm{LC}_{50}$ value was calculated to be $9.18 \mathrm{mg} / \mathrm{L}$ Durasoil ${ }^{\circledR}$ and a 50 -percent inhibition concentration $\left(\mathrm{IC}_{50}\right.$ ) value for reproduction was $9.07 \mathrm{mg} / \mathrm{L}$ Durasoil ${ }^{\circledR}$ (BES 2005d). In sediments, significant mortality was observed in $\mathrm{H}$. azteca exposed to application treatments equivalent to $1 \mathrm{gal} / 35 \mathrm{ft}^{2}$ and $1 \mathrm{gal} / 20 \mathrm{ft}^{2}$ Durasoil ${ }^{\circledR}$ (BES 2005e). 
A single study using a terrestrial species showed no toxicity using earthworms exposed to relevant application rates as high as $1 \mathrm{gal} / 20 \mathrm{ft}^{2}$ (BES 2005f).

\section{Conclusions}

EnviroKleen ${ }^{\circledR}$ and Durasoil ${ }^{\circledR}$ are mixtures of hydrocarbon compounds with little or no toxicity expected to humans or ecological receptors. Due to their hydrophobicity they are likely to sorb to soils and sediments and be relatively stable in these environments and therefore unlikely to be transported in water. However, as a result, they may cause some limited toxicity in sediments as a result of ingestion of sediment particles with sorbed product. Limited terrestrial toxicity data are available to determine the potential for toxicity in soil.

\section{Polysaccharide stabilizers}

\section{Formulation, use, and properties}

Surtac ${ }^{\circledR}$ is an organic compound based stabilizer that attracts soil moisture and agglomerates soil particles. Surtac ${ }^{\circledR}$ is a mixture of polyols, partially hydrogenated heterocyclics, and around 32 to 35 percent water. Amounts of each component are trade secrets (personal communication with Chad Falkenberg, Soilworks ${ }^{\circledR}$, J uly 2006). However, in these personal communications, it was indicated that Surtac ${ }^{\circledR}$ contains basic ingredients including sugar, starch, soap, and trisodium phosphate. Chemical analysis at ERDC by gas chromatography with mass spectrometry detection revealed no quantifiable peaks.

Application of $\operatorname{Surtac}^{\circledR}$ requires a 1:3 dilution with water. It is recommended for use on helipads and roadways at a rate of 0.3 to $0.6 \mathrm{gal} / \mathrm{yd}^{2}$. In arid conditions, Surtac ${ }^{\circledR}$ may be effective up to 90 days.

The environmental fate of Surtac ${ }^{\circledR}$ is largely unknown. Surtac ${ }^{\circledR}$ is very soluble in water and has the potential to be transported in runoff water following rainfall events or as leachate in soils. The rate of decomposition and degradation in the environment has not been determined. However, efficacy studies indicated continued performance of the product 90 days after application in arid conditions, suggesting persistence in the absence of rainfall (Rushing et al. 2005). 


\section{Human toxicity}

Very little human toxicity is expected with Surtac ${ }^{\circledR}$. Polysaccharides, including the engineering substrates termed sugar, starch, and soap, are natural products of limited inhalation toxicity interest. Soaps might be capable of causing dermatitis, although of only minimal significance. Inhalation reference exposure concentrations should be kept below 1,000 ppm (Pierce 2006).

\section{Toxicity to ecological receptors}

No ecotoxicological data were found for Surtac ${ }^{\circledR}$.

\section{Conclusions}

No data were identified regarding the environmental fate and transport, as well as human health, and ecotoxicological properties of the polysaccharide dust stabilizers. However, the main ingredients of Surtac ${ }^{\circledR}$ are sugar, starch, and soap and are thus expected to pose little or no environmental hazards. 


\section{Exposure Assessment}

Exposure assessment is the process of measuring or estimating the intensity, frequency, and duration of human or wildlife exposure to an agent in the environment. This section discusses how soil stabilizers are distributed in the environment and estimates potential contact between the hypothetical receptor populations and stabilizers. The frequency and duration of the hypothetical contact have been assumed to occur routinely, although such contacts have not been observed or documented for the activities being evaluated (e.g., applicators and war fighters).

There are two basic steps in the exposure assessment for the hypothetical activities being evaluated. First, the exposure setting was characterized and receptor populations identified. Second, exposure pathways were identified and graphically presented in a conceptual model (CM). This second step also included qualitatively characterizing chemical sources, mechanisms of release, and exposure routes at theoretical exposure points. Conditions expected to be present and activity patterns of humans and wildlife indicate the presence of completed exposure pathways for contact with soil stabilizers (USEPA 2004).

\section{Identification and evaluation of receptor populations and exposure pathways}

For this evaluation, hypothetically exposed populations and associated exposure scenarios were developed and evaluated. These exposure scenarios were based on some of the types of activities that occur when stabilizers are applied to soils by applicators and subsequently through contact with these soils by war fighters during routine activities. Contact with the stabilizers could occur for applicators during preparation and application as well as war fighters inadvertently contacting soils treated with stabilizers. Wildlife receptors such as birds, mammals, invertebrates, plants, and aquatic organisms could also contact stabilizers applied to soils. Exposure assessment for stabilizers is shown separately below for humans and wildlife.

\section{Potential releases to and transport in the environment}

Release and transport of stabilizers to soils may result in contamination of secondary sources including surface water, ground water, air, and 
sediment. The potential migration pathways by which stabilizer components can move from source areas to receptor populations were considered in the development of the CM.

The following potential migration or retention mechanisms for stabilizers in the environment were considered during the development of the CM. Surface water runoff may transport stabilizers into surface water bodies. Chemicals released from surface water through volatilization may be dispersed in the air and then transported by vapor migration. Chemicals released to surface water may include free phase chemicals that may enter sediments. Chemicals in surface water may be released to sediment (through deposition and sorption), biota (through uptake), surface water (through runoff), and air (through volatilization). Chemicals in air may be transported to sediment and surface water through wet or dry deposition. Chemicals in sediment may be released to surface water (through desorption/sorption) and biota (through uptake).

The fate of stabilizers in the environment also depends on chemicalspecific characteristics, such as water solubility, potential for degradation and bioaccumulation, chemical molecular weight, application rates and methods, and environmental conditions such as wind speed, rainfall, and soil grain size (USEPA 2004). The potential for stabilizers to migrate in the environment were considered as the exposure pathways were evaluated and indicated in the CM.

\section{Potential exposure pathways for humans}

Identification of potentially contaminated media and identification of potential exposure pathways were made based upon our understanding of the uses of soil stabilizers and where these products may be applied. Exposure points indicated in the CM (Figure 1) were selected based on accessibility of treated soils and hypothetical activity patterns for applicators and war fighters. These exposure scenarios were assumed to contribute the majority of total exposure due to hypothetical activities. 


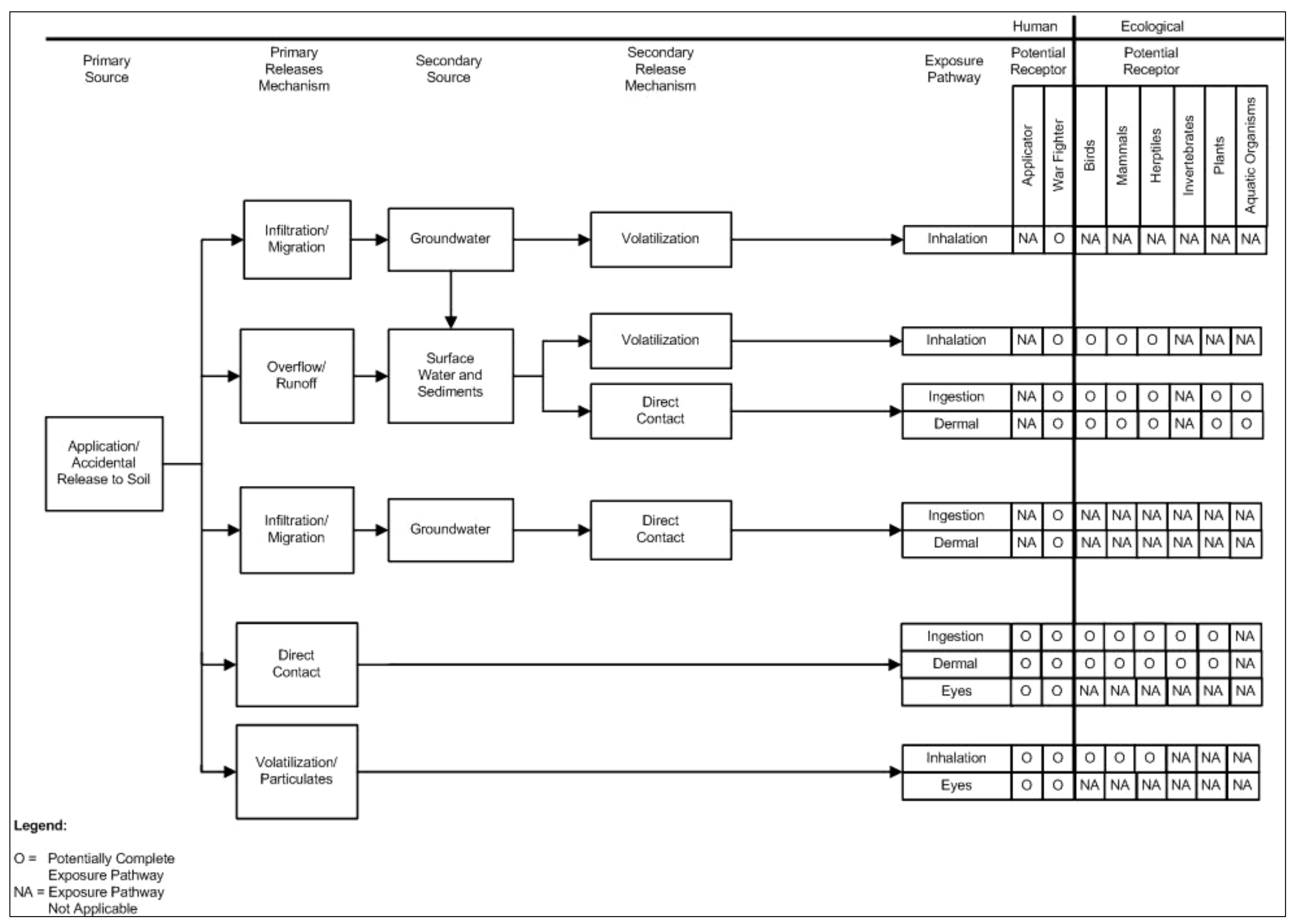

Figure 1. Conceptual model for human and ecological receptors potentially exposed to soil stabilizers. 
Complete exposure pathways for applicators and/ or war fighters as indicated in the CM for qualitative evaluation are as follows:

- ingestion of material directly or indirectly through ingestion of soil, sediment, surface water and groundwater

- inhalation of stabilizers in air

- dermal and eye contact directly with material during application or indirectly through contact with soil, surface water, sediments, and groundwater.

As shown in Figure 1, potentially complete exposure pathways are noted with an open circle. Potential exposure pathways applicable to stabilizers were represented in the $\mathrm{CM}$.

Figure 1 shows potentially complete pathways for applicators and war fighters. These activities represent direct exposure to materials during application or indirect contact with environmental media, since human receptors are not likely to purposefully ingest stabilizers. Direct contact with materials will occur with applicators mixing and applying material to soil. Contact with soil will occur for applicators that may accidentally slip, trip, or fall into soil where stabilizers are being applied or have been recently applied. In addition, war fighters may come in direct contact with material through potential drift or contact with soil after application. Soil contacted dermally could adhere to uncovered hands, arms, face, or other parts of the body where chemicals can absorb through the skin. Inhalation of stabilizers could occur when persons inhale airborne stabilizer particles. Inhalation of stabilizers could occur due to wind carrying liquid stabilizers as mists during application or when soils are physically disturbed and particles are otherwise released into the air.

Contact with sediments, surface water, or groundwater is limited to persons that may accidentally slip, trip, or fall into a body of water containing stabilizers. This can occur if a person washes stabilizer application equipment in a water body. Although this is not likely to occur routinely, the potential for this activity has been included here. If someone were to contact a surface water body, he might be exposed to stabilizers in surface water through incidental ingestion and dermal contact with surface water. This person could also be exposed to stabilizers through incidental ingestion and dermal contact with sediment. Sediments contacted dermally could adhere to the person's feet, hands, and lower legs where chemicals 
can absorb through the skin into the body. The sediment referred to in the CMs is located beneath the surface water.

War fighters have the potential to contact treated soils, sediments, surface water, or groundwater as part of training and mission activities (i.e., crawling on ground, contact with equipment, or passing through water). War fighters may accidentally slip, trip, or fall into soils containing cured stabilizers or into nearby water or sediment containing stabilizers transported from treated areas. If someone were to contact such stabilizers, he might be exposed to stabilizers through incidental ingestion, inhalation, and dermal contact. Soil, water, and sediment contacted dermally could adhere to exposed parts of the body where chemicals can absorb through the skin. Inhalation of cured or degraded stabilizers could occur when war fighters inhale airborne stabilizer particles. Inhalation of stabilizers could occur due to wind carrying stabilizers attached to airborne particles or when soils are physically disturbed (e.g., at a helipad) and particles are otherwise released into the air.

\section{Potential exposure pathways for wildlife}

Exposure pathways were considered complete only when stabilizers could migrate from a source and subsequently contact and be accumulated by an ecological receptor via one or more exposure routes (e.g., ingestion).

Ecological exposure pathways considered include:

- source(s) of stabilizers and their mechanism(s) of release to the environment

- transport medium (or media) and mechanism(s) of transfer from one medium to another

- point (or area) of potential receptor contact with stabilizers.

The potential exposure pathways incorporated each of these elements and are represented in the CM (Figure 1). The sources of stabilizers considered in this assessment are current and historical applications and accidental releases. Potential release mechanisms include surface water runoff, infiltration and migration, volatilization, erosion, and suspended sediment transport. Through these release mechanisms, stabilizers originating from past and/ or current applications could potentially be a source of exposure for ecological receptors. 
Stabilizers in secondary source materials may be released via several mechanisms, including incorporation into the food-web. Stabilizers released to surface water and/ or sediment can be contacted or ingested by aquatic and terrestrial receptors. Terrestrial receptors may directly contact or ingest surface water. Surface runoff could transport surface soilcontaining stabilizers to surface water and sediment, potentially exposing aquatic receptors. Through food-web interactions, aquatic receptors can be ingested, in turn, by higher trophic level receptors.

Complete dermal exposure pathways for ecological receptors to media such as sediments are difficult to document; for many receptors (e.g., mammals grooming fur), ingestion of stabilizers will likely occur before actual dermal contact occurs.

\section{Wildlife pathways analysis}

Exposure pathways are routes by which a constituent migrates from a source to a receptor. Pathways that are potentially complete for stabilizers are listed and discussed below:

- Surface water: Direct contact (dermal and respiratory) and ingestion of surface water are potentially complete pathways to aquatic and terrestrial receptors, respectively.

- Sediment: Sediment contact and ingestion potentially occur only for benthic receptors (e.g., aquatic benthos and bottom feeding fish) because sediment will be substantially washed off items consumed by terrestrial receptors feeding on organisms inhabiting surface waters.

- Soil: Ingestion of soil by biota and direct uptake of stabilizers by vegetation are potentially complete exposure pathways. Soils will be substantially washed off items consumed by terrestrial and avian receptors feeding on organisms inhabiting surface waters.

- Ground water: Ground water pathways are not complete for ecological receptors as they are not directly contacted until it reaches the surface either as a seep or becomes surface water.

- Air: Air exposure pathways are not well characterized for ecological receptors and, therefore, were not considered complete.

- Biota: Direct ingestion of biota (including fish and crustaceans) by higher trophic level ecological receptors is a potentially complete exposure pathway. 
These exposure pathways served as one component of the CM. The diagram depicting exposure pathways for ecological receptors are presented in Figure 1.

\section{Potential receptors}

For this evaluation, hypothetically exposed human and wildlife populations were evaluated. Routine contact with the stabilizers could occur for applicators and war fighters inadvertently contacting soils treated with stabilizers. Wildlife receptors such as birds, mammals, invertebrates, plants, and aquatic organisms could also directly or indirectly contact stabilizers applied to soils.

\section{Human receptors}

Receptor populations and potential exposure pathways have been identified with respect to proximity to contaminated media, theoretical activity patterns, and the presence of sensitive subgroups. As discussed above, these receptor populations are largely limited to applicators that apply the stabilizers to soils, persons who may wash stabilizer equipment in a water body, and the war fighter that contacts soil during training and operational activities. As a standard part of quantitative risk evaluation, regulatory guidance requires that subpopulations that may be more sensitive to chemical exposures be evaluated. The subpopulations evaluated typically include infants and children, elderly persons, pregnant and nursing women, and people with chronic illnesses. These groups are included in the regulatory guidance because they may be at higher risk due to unique behavior patterns or physical conditions. For example, children may be more likely than adults to contact soil, sediment, and surface water due to play activities. Although consideration has been given to these subpopulation categories in this evaluation, the mostly restricted access to soils treated on military lands targeted for stabilizer application makes routine contact for such individuals highly unlikely. If such individuals were to contact these soils, it would be as a trespasser. However, the trespasser exposures would be expected to be much less than the war fighter and applicator.

\section{Ecological receptors}

Specific ecological receptor groups were selected based on the evaluation of assessment endpoints and exposure pathways previously described. The 
receptor selections were limited to those receptors that are most likely to contact soils treated with stabilizers in the field. These receptors include birds (e.g., passerines such as robin and granivorous birds such as quail), mammals (e.g., rodents), reptiles and amphibians (a.k.a. herptiles; e.g., lizards), soil invertebrates (e.g., earthworms), plants (herbaceous vegetation such as grasses and shrubs), and aquatic organisms such as fish and benthic invertebrates. Receptors most likely to contact stabilizers are those species that are not mobile (sessile) or have limited mobility such as plants and soil invertebrates (e.g., pill bugs and earthworms) that may be contacted by stabilizer applications. Because stabilizers are commonly used in arid environments, species such as lizards are also likely to contact stabilizer-treated soils that have cured. Stabilizers that are water-soluble have a greater potential to reach water bodies where they can contact fish and other aquatic and benthic receptors. Persons washing applicator equipment in water bodies also facilitate contact between stabilizers and aquatic receptors.

\section{Conceptual model (CM)}

A CM is a graphical representation used to identify: (1) all potential or suspected sources of contamination; (2) release and potential migration mechanisms; and (3) potential exposure pathways, including receptors, which lead to an exposure point (Figure 1). It was assumed that future land use would not change. Therefore, future exposure populations and pathways were assumed to be the same as those evaluated under current conditions.

The symbols used in the CM are as follows:

- Open Circle represents potentially complete exposure pathways that are likely to contribute significantly to exposure.

- Not Applicable represents exposure pathways that are not applicable for a particular receptor.

In general, an exposure pathway describes the course a chemical takes from the source to the exposed individual. An exposure pathways analysis links the source, location, and type of environmental release with population location and activity patterns to determine the significant pathways of exposure. An exposure pathway is considered complete only if all four of the following elements are present: (1) a source and mechanism of chemical release to the environment; (2) an environmental retention or 
transport medium (e.g., sediment, surface water) for the released chem.ical; (3) a point of potential contact with the contaminated medium (exposure point); and (4) an exposure route (e.g., ingestion, inhalation, dermal contact) at the contact point.

In summary, this exposure assessment indicated that a select group of human and ecological receptors can plausibly contact dust stabilizers. Potential human receptors are applicators, persons who may wash applicator equipment in a water body, and the war fighter. Persons in these groups can most likely contact stabilizers directly or via incidental ingestion of soil, dermal contact, and inhalation of airborne particles. Ecological receptors most likely to contact stabilizers are those that are immobile such as plants and soil invertebrates. In arid environments, species such as lizards could be exposed through direct contact of stabilizer-treated soils or through inhalation of volatile compounds or particulates derived from the stabilizer products. Water soluble stabilizers can be mobilized via surface runoff and reach nearby water bodies where aquatic and benthic receptors can contact these materials. 


\section{Comparative Risk}

Dust control during military activities is a growing concern due to increased training and operational activities in arid and other environments around the world. As part of these activities, wheeled and tracked equipment and aircraft may suspend arid soils and impact the ability for the military to successfully conduct operations (Rushing et al. 2005). Dust stabilizers are used by DoD to meet air quality standards, reduce erosion and maintenance costs on unpaved road surfaces, and reduce fugitive dust during military training and maneuvering activities. The DoD has historically used readily available petroleum-based organics such as asphalt emulsions, crude oil, gasoline, and diesel fuel for dust abatement (USAEC 2006). Such petroleum-based products work by forming a crust or protective surface on the soil (Bolander and Yamada 1999; Lohnes and Coree 2002; Tingle et al. 2004; USEPA 2004).

The primary advantage for using petroleum-based products is that they are readily available during maneuvers and training exercises as these products are also used to fuel military vehicles and are already in place. However, petroleum-based products (i.e., diesel, crude oil, fuel oil) are no longer advised for use because the fate and adverse effects on humans and the environment are relatively well known and documented (Eisler 1985). Such products contain hydrocarbons (some of which are known carcinogens) to which humans and wildlife can be exposed (McMillen et al. 2001). When applied to soils, hydrocarbons in petroleum-based stabilizers can be ingested or cling to the skin or dermis of animals. Volatile components, mists from application, and suspended soil particles can be inhaled. Hydrocarbons can be transported to subsoil and groundwater via leaching or dissolution. If groundwater reaches the surface, it can be ingested or its emissions inhaled.

\section{Human health}

There are three main human exposure routes for dust stabilizers: dermal, inhalation, and ingestion. These exposure routes have been highlighted in Chapter 3 in the conceptual model and described for applicators, persons washing application equipment, and the war fighter, all via incidental exposure. For the purposes of this analysis, the polysaccharide stabilizer Surtac $^{\circledR}$ is of limited concern for exposures through ingestion, inhalation, 
and dermal contact and will not be discussed in any further detail in this section. The other two stabilizer types may have some limited toxicity issues as described in Chapter 2. Current practices include the use of fuels and fuel oils and will be used for the comparison with the polymer emulsion and synthetic hydrocarbon products where appropriate.

\section{Dermal absorption and toxicity}

Dermal exposure to dust stabilizer products is most likely to occur during preparation, application, and washing stabilizer application equipment or from direct contact to soils. Data available from the manufacturers indicate the polymer emulsions and synthetic hydrocarbons do not pose a significant toxicity hazard and may cause slight skin irritations from prolonged contact. Dermal toxicity values were reported for Envirotac II ${ }^{\circledR}$ and EnviroKleen ${ }^{\circledR}$ in rabbits; acute toxicity $\mathrm{LD}_{50}$ values were greater than 5 and $2 \mathrm{~g} / \mathrm{kg}$, respectively. In comparison to other materials currently used, such as diesel fuel (fuel oil \#2), dermal toxicity is limited to irritation and blistering. Acute toxicity from diesel in mice occurred at concentrations as high as 20 to $40 \mathrm{~g} / \mathrm{kg} /$ day, and no toxicity was observed at 2 to $8 \mathrm{~g} / \mathrm{kg} /$ day (NTP 1986). Similarly, gasoline did not cause any acute toxicity (12-day) in studies using rabbits at concentrations as high as $8 \mathrm{~g} / \mathrm{kg}$ (Beck et al. 1983). These results suggest limited dermal toxicity except for some skin irritation. The potential for these effects can be mitigated through the use of personal protection (i.e., gloves and protective clothing).

\section{Inhalation}

Inhalation exposures are most likely to occur during preparation and application of the materials to soil. Polymer emulsions have the potential to cause some irritation associated with uncured or unpolymerized constituents. However, due to the complexity of the materials, it is difficult to determine these constituents. One constituent of the polymer products is vinyl acetate (vinyl acetate concentration in Soiltac ${ }^{\circledR}$ measured by ERDC was $375 \mathrm{mg} / \mathrm{L}$ ). Exposure to vinyl acetate should be minimized where possible and may pose a larger health hazard than current use of diesel or other oils (Table 2). The synthetic hydrocarbon stabilizers may cause irritation of the lungs and potentially cause fibrosis with deposition of the product in the lungs. No acute toxicity is expected through inhalation exposures (EnviroKleen ${ }^{\circledR}$ manufacturer's data). Therefore, exposure limits in units of $\mathrm{mg} / \mathrm{m}^{3}$ have been recommended by ACGIH based on product constituents. However, proper handling and application procedures, 
including the use of personal protective gear, may minimize the potential for inhalation exposures.

Table 2. Inhalation exposure limits and reference exposure calculations.

\begin{tabular}{|l|l|l|}
\hline Material & ACGIH (TWA, ppm) ${ }^{1}$ & $\begin{array}{l}\text { Inhalation Reference Exposure } \\
\text { Concentrations }\end{array}$ \\
\hline Gasoline & $890 \mathrm{mg} / \mathrm{m}^{3}$ & NA \\
\hline \#2 Diesel Fuel & $100 \mathrm{mg} / \mathrm{m}^{3}$ & NA \\
\hline Vinyl acetate & $30 \mathrm{mg} / \mathrm{m}^{3}$ & $200 \mathrm{mcg} / \mathrm{m}^{3}$ \\
\hline Polymer Emulsion Stabilizers & NA & $200 \mathrm{mcg} / \mathrm{m}^{3}$ \\
\hline $\begin{array}{l}\text { Synthetic Hydrocarbon } \\
\text { Stabilizers }\end{array}$ & $5 \mathrm{mg} / \mathrm{m}^{3}$ & $200 \mathrm{mcg} / \mathrm{m}^{3}$ \\
\hline Polysaccharide Stabilizers & None & $1000 \mathrm{mcg} / \mathrm{m}^{3}$ \\
\hline
\end{tabular}

1 ACGIH (1999-2000).

\section{Ingestion}

No acute toxicity is expected for the polymer emulsion or synthetic hydrocarbon stabilizers. Acute toxicity values $\left(\mathrm{LD}_{50}\right)$ for rats exposed to Envirotac II ${ }^{\circledR}$ and EnviroKleen ${ }^{\circledR}$ were greater than $5 \mathrm{~g} / \mathrm{kg}$. These values are similar to reported acute $L D_{50}$ values in rats for various solvents and oils such as benzene ( $3.3 \mathrm{~g} / \mathrm{kg})$, ethylene glycol $(5.9 \mathrm{~g} / \mathrm{kg})$, ethanol (7.1 g/ kg), and diesel fuel oil \#2 (12.0 to $17.5 \mathrm{~g} / \mathrm{kg}$ ) (HSDB 2006). The potential for effects associated with long-term exposure to the polymer emulsion or hydrocarbon stabilizers is unknown.

\section{Carcinogenicity}

Current practices employ the use of fuel oils and crude oil for dust stabilization. For the purposes of comparing current practices to the dust stabilizers in this report, a summary of cancer classification is provided in Table 3 (HSDB 2006). Based on this summary, the use of crude oil may pose a greater risk to applicators and war fighters than the polymer emulsion and synthetic hydrocarbons. 
Table 3. Cancer classification of dust stabilizers and relevant materials.

\begin{tabular}{|l|l|}
\hline Material & Carcinogen Classification (EPA/IARC) \\
\hline Gasoline & $\begin{array}{l}\text { Constituent (1 to } 5 \text { percent benzene) classified as a human } \\
\text { carcinogen (A/1) }\end{array}$ \\
\hline \#2 Diesel Fuel & Not considered a carcinogen \\
\hline Crude oil & $\begin{array}{l}\text { Constituent (1 percent benzene) classified as a human carcinogen } \\
\text { (A/1) }\end{array}$ \\
\hline Vinyl acetate & Possible human carcinogen (C/2B) \\
\hline $\begin{array}{l}\text { Polymer Emulsion } \\
\text { Stabilizers }\end{array}$ & $\begin{array}{l}\text { Constituent in some polymers (ND to } 375 \mathrm{mg} / \mathrm{L} \text { vinyl acetate) is a } \\
\text { possible human carcinogen (C/2B) }\end{array}$ \\
\hline $\begin{array}{l}\text { Synthetic Hydrocarbon } \\
\text { Stabilizers }\end{array}$ & Not considered a carcinogen \\
\hline
\end{tabular}

1 Carcinogen classification based on Environmental Protection Agency (EPA) and International Agency for Research on Cancer (IARC) terminology.

Vinyl acetate and acrylic polymer based stabilizers (Soiltac ${ }^{\circledR}$, SoilSement ${ }^{\circledR}$, and Envirotac II ${ }^{\circledR}$ ) are stable in soils after curing and are thus unlikely to be available to terrestrial organisms or be transported in runoff water. The limited available mammalian data suggest that acrylic polymers are relatively non-toxic. However vinyl acetate, if present, is a potential carcinogen. When used in large volumes, exposure may occur during handling and application. Therefore, steps should be taken to limit exposure during preparation, application, and cleanup. Data gaps include degradation information, terrestrial toxicity, and potential for polymers to result in inhalation exposures after application. As a result of the data gaps, it is difficult to quantitatively compare the risks of these materials with other stabilizer products.

EnviroKleen ${ }^{\circledR}$ and Durasoil ${ }^{\circledR}$ are hydrocarbon compound mixtures that have no demonstrated evidence of toxicity to humans. Due to their hydrophobicity they are likely to sorb to soils and sediments and be relatively stable in these media; therefore, they are unlikely to be transported in water runoff except when sorbed to particles transported during erosion. However, they may cause some limited toxicity in soil as a result of ingestion of particles containing sorbed product.

Polysaccharide stabilizer products include the engineering substrates sugar, starch, and soap, which are natural products of limited inhalation toxicity interest. Soaps might be capable of causing dermatitis, although of only minimal significance. No data exist regarding the environmental fate, 
transport, and human health toxicity. Due to its composition, Surtac ${ }^{\circledR}$ is very soluble in water and may have a potential to be transported in water following rainfall events. However, the main ingredients of Surtac ${ }^{\circledR}$ are sugar, starch, and soap and are thus expected to pose little or no environmental hazards.

In summary, the vinyl acetate and acrylic polymers Soiltac ${ }^{\circledR}$, SoilSement ${ }^{\circledR}$, and Envirotac $\mathrm{II}{ }^{\circledR}$; the hydrocarbon compound mixtures EnviroKleen ${ }^{\circledR}$ and Durasoil ${ }^{\circledR}$; and the polysaccharide compound Surtac ${ }^{\circledR}$ all appear to be relatively nontoxic to humans. Comparing across various dust suppression agents, the bio-derived products such as the polysaccharides exhibit much lower toxicity. Thus, the hierarchy of controls can be less strict than for synthetic molecules such as vinyl acetate, acrylic acid, and hydrocarbons. For vinyl acetate, acrylic acid, and hydrocarbons, extensive respiratory and dermal protection is necessary during formulation and typically during applications. Therefore, care should be made to follow label directions and adhere to manufacturer's recommendations to wear protective clothing, eyewear, and gloves during application (Appen$\operatorname{dix}$ A to F). Until further information or any compelling data are obtained, stabilizer selection may be more appropriately determined by considering non-health related factors such as effectiveness in a given environment and the associated costs for transporting and storing the materials on site. A lingering concern are the gaps in our understanding of the degradation, potential for polymers to result in inhalation exposures, and the effects of trace amounts of vinyl acetate in treated soils for the vinyl acetate polymers.

\section{Environmental risk}

After efficacy of dust control, the environmental toxicity of dust stabilizers is a primary selection criterion for dust stabilizers within the DoD. Thus, it would be useful to compare the relative toxicity of various historically used petroleum-based stabilizers with more recently developed polymer stabilizers to determine potential environmental benefits of using the newer stabilizer products under consideration. For the purpose of comparing relative toxicity, data derived from aquatic studies were used for this analysis. While exposure to terrestrial species is important, these analyses are difficult to complete due to the lack of toxicity data.

A simple means for making such toxicity determinations is to use the acute aquatic toxicity rating scale developed by the U.S. Fish and Wildlife 
Service (USFWS 1984). This scale rates chemicals based on readily available toxicity information for aquatic organisms. The USFWS scale uses an $\mathrm{LC}_{50}$ value as the basis for comparison, which is the concentration of a chemical or substance that would be lethal to 50 percent of a population of the test organisms (e.g., fish, benthic invertebrate) within 48 to 96 hours. Each substance is rated into one of seven categories. The least toxic category is termed "relatively harmless" and includes substances for which the $\mathrm{LC}_{50}$ value is $>1,000 \mathrm{mg} / \mathrm{L}$; the most toxic category is termed "super toxic" and includes substance for which the $\mathrm{LC}_{50}$ value is $<0.01 \mathrm{mg} / \mathrm{L}$. This rating scale was used to determine the relative aquatic toxicity of petroleumbased stabilizer products and the six stabilizers that are the subject of this report.

Valid comparisons of various soil stabilizers using the USFWS rating scale must include toxicity data that are comparable with respect to the scale's endpoint (48 to $96 \mathrm{hr} \mathrm{LC}_{50}$ values) and include freshwater species that may be impacted by stabilizer runoff. For these reasons, the comparisons were made using acute ( 24 to $96 \mathrm{hr}$ ) LC50 values for freshwater fish, primarily fathead minnows (Pimephales promelas) and salmonids such as rainbow trout (Oncorhynchus mykiss). Toxicity data for the subject stabilizers were obtained from manufacturer's data and are also presented in Appendices A through F. No aquatic toxicity data for Surtac ${ }^{\circledR}$ were found. Freshwater toxicity data for unleaded gasoline, diesel fuel, lube oil, and two types of crude oil (Kuwait and Prudhoe Bay crude) were obtained from the published literature (Frankenfeld et al. 1975; Moles et al. 1979; Poirier et al. 1986; Lockhart et al. 1987; Rice 1973; Vandermeulen and Hrudey 1987).

Comparisons of various petroleum stabilizers with recently developed stabilizers indicated distinct toxicity differences between the groups (Figure 2). The toxicity data for unleaded gasoline, diesel fuel, lube oil, Kuwait crude, and Prudhoe Bay crude generally ranged from 1 to $300 \mathrm{mg} / \mathrm{L}$, which fall into the slightly to moderately toxic categories. Conversely, the five stabilizers for which data were available indicated LC50 values ranging from a low of $500 \mathrm{mg} / \mathrm{L}$ up to 10,000 $\mathrm{mg} / \mathrm{L}$, indicating that these products were in the practically nontoxic to relatively harmless categories. 


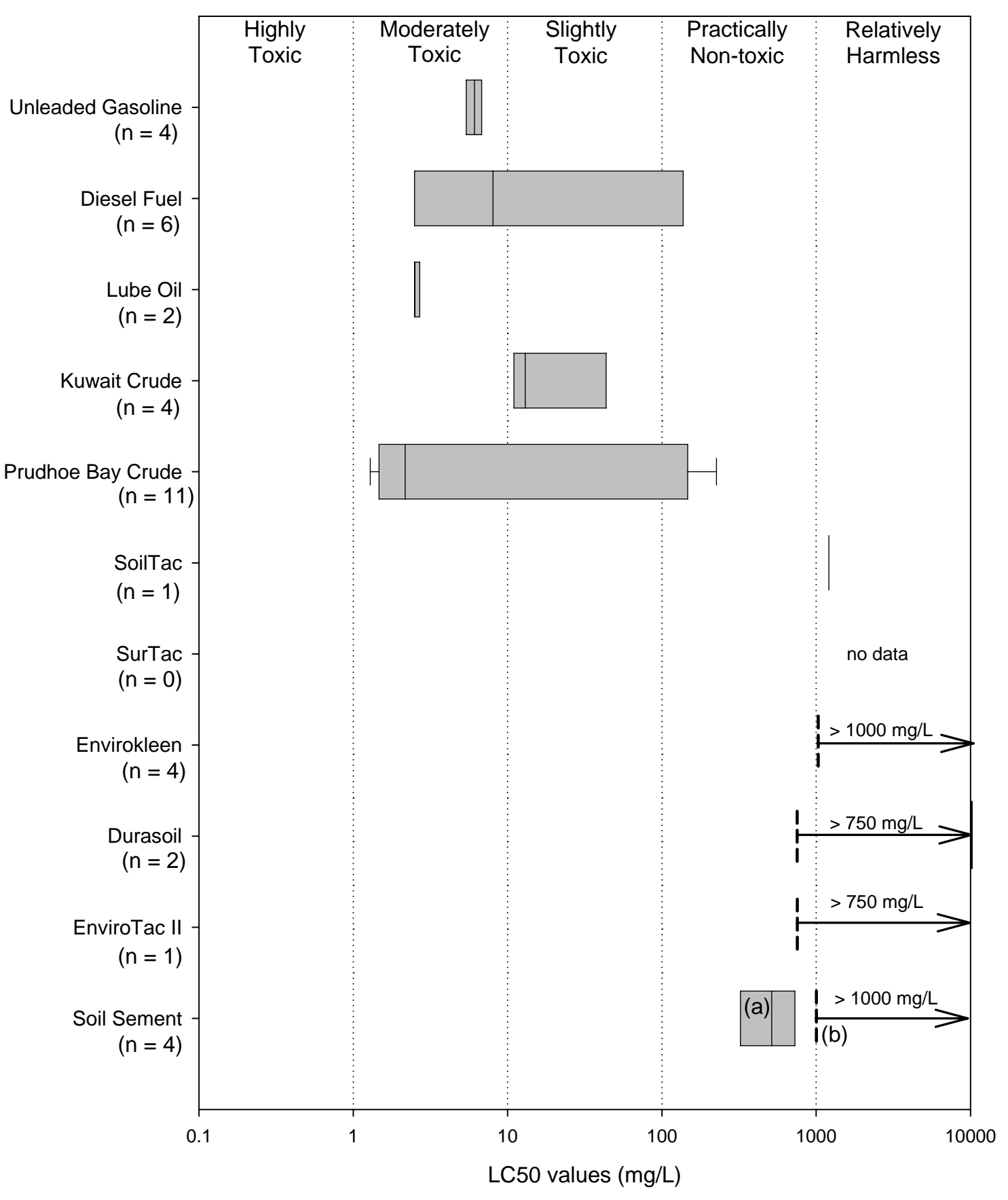

All toxicity values are for freshwater fish (24- to 96-hr exposures using mostly fathead minnows and rainbow trout) for consistency. Boxes represent 90 percent of the data range; whiskers indicate outliers; and black vertical lines within boxes show the median LC 50 value. Dashed vertical lines for EnviroKleen ${ }^{\circledR}$, Durasoil ${ }^{\circledR}$, Envirotac II ${ }^{\circledR}$, and Soil-Sement ${ }^{\circledR}$ indicate the highest concentration tested at which mortality was insufficient to calculate an LC50 value. Acute toxicity rating scales are from U.S. Fish and Wildlife Service (1984). (a) = Rainbow trout data for Soil Sement ${ }^{\circledR}$; (b) $=$ Fathead minnow data for Soil Sement ${ }^{\circledR}$

Figure 2. Graphical summary of median lethal concentrations inducing 50 percent lethality $\left(\mathrm{LC}_{50}\right)$ for historically used petroleum and more recently formulated soil stabilizer products. 
Many toxicity studies available from the manufacturers showed $\mathrm{LC}_{50}$ values that were greater than the highest concentrations tested, usually around 750 to $1,000 \mathrm{mg} / \mathrm{L}$. In the context of other chemicals, LC50 values for fathead minnows (P. promelas) exposed to sodium chloride range from 6,400 to $9,000 \mathrm{mg} / \mathrm{L}$ (USEPA 2006). These data clearly show the more recently developed stabilizer products are much less toxic to aquatic organisms than the petroleum-based products used historically by the DoD.

Figure 2 also demonstrates the lack of aquatic toxicity data available for these products. There was only one fish study which reported an $\mathrm{LC}_{50}$ value. Data reporting no effect concentrations were available for three of the stabilizers and none for a fourth stabilizer, Surtac ${ }^{\circledR}$. While the toxicity comparison focused on fish, the lack of toxicity data holds true for other aquatic species such as aquatic invertebrates as well. It is also noted that these studies were obtained directly from the manufacturers and are unpublished. Published toxicity data are needed for all six stabilizer products.

The ecotoxicological data for stabilizers utilizing vinyl acetate and acrylic polymers are limited to aquatic studies with uncured polymer. As a result, these studies represent a worst-case scenario of material reaching an aquatic receptor in the most unstable form. The greatest concern when using these stabilizers is the unknown formulation composition for the polymer thus making it difficult to estimate environmental risk parameters used to determine fate and transport.

The hydrocarbon compound mixtures EnviroKleen ${ }^{\circledR}$ and Durasoil ${ }^{\circledR}$ have no demonstrated toxicity to ecological receptors. Due to their hydrophobicity, they are likely to sorb to soils and sediments and be relatively stable in these environments and, therefore, unlikely to be transported in water. However, they may cause some limited toxicity in sediments if sediments containing sorbed product are ingested. Few terrestrial toxicity data are available to determine the potential for toxicity in soil.

Polysaccharide stabilizer products include sugar, starch, and soap as main components; these are natural products of limited inhalation toxicity interest. Due to its composition, Surtac ${ }^{\circledR}$ is very soluble in water and may have a potential to be transported in water following rainfall events. No data exist regarding the environmental fate, transport, and 
ecotoxicological properties. However, the main ingredients of Surtac ${ }^{\circledR}$ (sugar, starch, and soap) are expected to pose little or no environmental hazards.

In summary, the vinyl acetate and acrylic polymers Soiltac ${ }^{\circledR}$, SoilSement ${ }^{\circledR}$, and Envirotac II ${ }^{\circledR}$; the hydrocarbon compound mixtures EnviroKleen ${ }^{\circledR}$ and Durasoil ${ }^{\circledR}$; and the polysaccharide compound Surtac ${ }^{\circledR}$ all appear to be relatively nontoxic to the environment. No compelling information exists indicating that any of these stabilizers would be more toxic than another in field conditions when following label directions. It is unlikely that trophic transfer will be observed for these materials based on chemical composition, chemical properties, and large polymer size. However, there are some concerns that remain regarding gaps in our understanding of the fate, transport, and toxicity of the stabilizers studied. 


\section{Uncertainty and Data Gaps}

This section identifies sources of uncertainty and data gaps associated with the analysis of existing information outlined in previous sections of this report. Specific sources of uncertainty and data gaps are discussed below.

\section{Missing information (data gaps)}

Information gaps where sources, mechanisms of exposure, and exposure pathways are not identified or important aspects of the ecology are not known can affect risk estimates. Information concerning the toxicity of the six products studied leaves a substantial data gap. Nearly all toxicity data are unpublished and only available from the manufacturers. Toxicity data are lacking for complete animal kingdoms for some stabilizers. While the relative toxicity of five of the six subject stabilizers were in the practically nontoxic to relatively harmless range, it is unclear whether the lack of aquatic toxicity based on manufacturers' data holds true for other species. Confirmatory studies are needed to determine the toxicity with more certainty and to determine the toxicity of these products to other species that can reasonably contact these products in the field. Environmental fate data for many of the stabilizers are also unknown. Data gaps specifically identified in this report are:

- information on chemical composition

- environmental fate (i.e., degradation and partitioning) and transport information for all products

- inhalation exposure data for all polymer emulsions

- toxicity of all stabilizers to emergent and established plants

- toxicity of all stabilizers to soil invertebrates

- toxicity of all stabilizers to terrestrial vertebrates (i.e., reptiles)

- toxicity of all stabilizers to aquatic organisms, especially species other than fish

- toxicity of cured acrylic polymer for terrestrial and aquatic species

- toxicity of Soiltac ${ }^{\circledR}$, Durasoil ${ }^{\circledR}$, and Surtac ${ }^{\circledR}$ to mammals.

\section{Errors in the conceptual model}

If relationships between sources and receptors are missing or incorrectly identified, risks could be under- or overestimated. Proper CM 
development can help reduce this uncertainty. In this report, the development of a comprehensive CM that identified all known potential pathways and receptor groups reduced the overall uncertainty of missing pathways and receptors. However, due to the various applications for these materials and activities associated with training and mission-related activities, it is difficult to determine intact exposure pathways for the war fighter. A concern that remains is the fate of these stabilizers in the environment after application. These characteristics are best determined from knowledge of the active and inactive components of these complex mixtures, which is difficult to determine due to the proprietary nature of the products.

\section{Use of representative species}

Representative species such as lizards and soil invertebrates were selected to signify the different species groups that could potentially contact dust stabilizers in arid regions. These species were of specific interest following discussions with personnel involved in efficacy testing and use of materials. As a result of the broad geographical locations for the use of these products, species not identified in the CM could also potentially contact stabilizers. However, the potential exposure and effects of stabilizers is not likely to be uniform across species. Therefore, hazards to species not identified in this report could be higher or lower than those estimated for species evaluated in this report. 


\section{Conclusions}

Personnel of ERDC, Vicksburg, MS, and Navy Environmental Health Center (NEHC), Portsmouth, VA, evaluated the environmental fate and effects of six commercially available dust stabilizer products. As part of the evaluation, a relative risk comparison was made of the six materials to other materials that have been used historically to control dusts (i.e., diesel, crude oil, fuel oil). Data for this evaluation were obtained primarily through literature review, communication with the manufacturers of the products, and through some limited analytical chemistry. Data gaps and uncertainties were also identified and described. The following conclusions were derived from the results of the evaluation, with each stabilizer group presented separately along with general conclusions applicable to all stabilizers studied.

\section{Vinyl acetate and acrylic polymer dust stabilizers}

- Vinyl acetate and acrylic polymers are stable in soils after curing and are unlikely to be available to terrestrial organisms or be transported in runoff water. The limited mammalian data suggest the polymer is relatively non-toxic. If present, the vinyl acetate fraction is a potential carcinogen. When used in large volumes, potential exposure may occur during handling and application. Precautions should be taken to limit exposure during preparation, application, and cleanup.

- The ecotoxicological data are limited to aquatic studies with uncured polymer and represent a worst-case scenario for materials reaching aquatic receptors. Because the exact formulation composition for the polymer is unknown, it is difficult to estimate environmental risk parameters used to determine fate and transport.

- Data gaps for these stabilizers include degradation information, terrestrial toxicity, and potential for polymer to result in inhalation exposures.

\section{Synthetic hydrocarbon mixture dust stabilizers}

- EnviroKleen ${ }^{\circledR}$ and Durasoil ${ }^{\circledR}$ are mixtures of synthetic hydrocarbon compounds with little or no toxicity to humans or ecological receptors. 
- Their hydrophobicity indicates that they are likely to sorb to soils and sediments and be relatively stable in these environments and therefore unlikely to be transported in water.

- Hydrocarbon-based stabilizers may cause some limited toxicity in sediments as a result of ingestion of sediment particles with sorbed product.

- Data gaps for these stabilizers include degradation information, terrestrial toxicity, and potential for polymer to result in inhalation exposures.

\section{Polysaccharide dust stabilizers}

- The main ingredients of Surtac ${ }^{\circledR}$ are sugar, starch, and soap and are thus expected to pose little or no environmental hazards.

- No data exist regarding the environmental fate and transport as well as human health and ecotoxicological properties.

\section{General}

- The exposure assessment indicated that applicators and the war fighter can potentially come into contact with dust stabilizers. Persons in these groups can most likely contact stabilizers via direct contact with the material or through incidental ingestion of soil, dermal contact, and inhalation of airborne particles.

- Ecological receptors most likely to contact stabilizers are those that are immobile or have limited mobility such as plants and soil invertebrates, respectively. In arid environments, species such as lizards could contact stabilizer-treated soils. In addition, organisms that burrow may be exposed through inhalation of volatile compounds or particles derived from the dust stabilizers. Stabilizers that are water-soluble can be mobilized via surface runoff and reach nearby water bodies where aquatic and benthic receptors can contact these materials. Stabilizers that are insoluble may be transported in runoff water through the transport of product sorbed to soil and sediment particles.

- A comparison between petroleum stabilizers and the nontraditional stabilizers clearly showed the stabilizer products in the current evaluation are much less toxic to aquatic organisms than the petroleum products used historically by the DoD. The acute aquatic $\mathrm{LC}_{50}$ values for unleaded gasoline, diesel fuel, lube oil, Kuwait crude, and Prudhoe Bay crude generally ranged from 1 to $300 \mathrm{mg} / \mathrm{L}$, which are considered to be slightly to moderately toxic. Conversely, the five commercially available 
stabilizers for which data were available indicated $\mathrm{LC}_{50}$ values ranging from a low of $500 \mathrm{mg} / \mathrm{L}$ up to $>10,000 \mathrm{mg} / \mathrm{L}$, indicating that these products are considered practically nontoxic to relatively harmless as defined by the USFWS (1984).

- There is a lack of aquatic toxicity data available for all the products studied. While the relative toxicity of five of the six subject stabilizers were in the practically nontoxic to relatively harmless range, it is unclear whether the lack of aquatic toxicity based on unpublished manufacturers' data holds true for other species. Confirmatory studies are needed to determine the toxicity with more certainty and document these effects.

- There is a need to determine the toxicity of these products to other species such as plants, soil invertebrates, and reptiles that can reasonably contact these products in the field.

\section{Comparative risk}

- Comparing human health risks across various dust suppression agents, the bio-derived products such as the polysaccharide stabilizers exhibit a much lower order of toxicity (at least 50-fold lower toxicity). Thus, the hierarchy of controls can be less strict than for synthetic molecules used in dust stabilizer formulations containing vinyl acetate, acrylic acid, and hydrocarbons.

- For vinyl acetate, acrylic, and hydrocarbon dust stabilizers, extensive respiratory and dermal protection is necessary during formulation and typically during applications. Demonstration projects may show that there are no, or limited, emissions, suggesting that exposure will not occur, thus eliminating the potential risk.

- The vinyl acetate and acrylic polymers Soiltac ${ }^{\circledR}$, Soil-Sement ${ }^{\circledR}$, and Envirotac II ${ }^{\circledR}$; the hydrocarbon compound mixtures EnviroKleen ${ }^{\circledR}$ and Durasoil ${ }^{\circledR}$; and the polysaccharide compound Surtac ${ }^{\circledR}$ all appear to be relatively nontoxic to the environment. 


\section{References}

ABC Laboratories. 2002. EnviroKleen environmental data: Acute and chronic aquatic toxicity. Project report to Midwest Industrial Supply for EPA Environmental Technology Verification Program. http://www.midwestind.com/uploads/AQTOX2909.pdf.

Addo, J . Q., T. G. Sanders, and M. Chenard. 2004. Road dust suppression: Effect on maintenance stability, safety and the environment. Phases 1- 3. Mountain Plains Consortium, MPC Report No. 04-156. www.mountain-plains.org/pubs/pdf/MPC-04156.pdf.

American Council of Government Industrial Hygienists (ACGIH). 1999- 2000. Guide to occupational exposure values. Cincinnati, $\mathrm{OH}$.

Beck, L. S., D. I. Hepler, and K. L. Hansen. 1983. The acute toxicology of selected petroleum hydrocarbons. In Proceedings, 1st Symposium on the toxicology of petroleum hydrocarbons, May 1982, Washington, DC, ed. H. N. MacFarland, L. E. Holdsworth, and J. A. MacGregor, 1- 12. Washington, DC: American Petroleum Institute.

Block Environmental Services (BES). 2005a. Aquatic toxicity testing results for Soilworks, LLC: Three 96-hour product LC-50 bioassays. Pleasant Hill, CA: Block Environmental Services.

. 2005b. Hazardous waste aquatic toxicity screening test results for one liquid sample (Project: Durasoil). Pleasant Hill, CA: Block Environmental Services.

. 2005c. Aquatic toxicity testing results for Soilworks, LLC: A 96-hour product LC-50 bioassays. Pleasant Hill, CA: Block Environmental Services.

. 2005d. Aquatic toxicity testing results for Soilworks, LLC: A three species chronic definitive bioassay. Pleasant Hill, CA: Block Environmental Services.

. 2005e. Whole sediment toxicity testing results for Durasoil: One definitive bioassay with the amphipod Hyalella azteca. Pleasant Hill, CA: Block Environmental Services.

. 2005f. Soil toxicity results for Durasoil: One definitive bioassay with the earthworm Eisenia fetida. Pleasant Hill, CA: Block Environmental Services.

Bolander, P., and A. Yamada. 1999. Dust palliative selection and application guide. Project Report 9977-1207-SDTDC. San Dimas, CA: USDA San Dimas Technology and Development Center.

Eisler, R. 1985. Polycyclic aromatic hydrocarbon hazards to fish, wildlife, and invertebrates: A synoptic review. U.S. Fish and Wildlife Service Biological Report 85(1.11). Laurel, MD: U.S. Fish and Wildlife Service.

Environmental Products and Applications, Inc. (EPI). 2000. MSDS for Envirotac II. Palm Desert, CA. http://www.envirotac.com/safety_sheet_1.pdf. 
Environmental Products and Applications, Inc. (EPI). 2001. Environmental data for Envirotac II. Palm Desert, CA. http://www.envirotac.com/aqua.pdf.

Epps, A., and M. Ehsan. 2002. Laboratory study of dust palliative effectiveness. J . Materials Civil Eng. 14(5):427-435.

Engineer Research and Development Center (ERDC). 2006. Environmental evaluation of dust stabilizer products. Technical Notes Collection Draft. Vicksburg, MS: U.S. Army Engineer Research and Development Center.

Ettinger, W. S. 1987. Impacts of a chemical dust suppressant/ soil stabilizer on the physical and biological characteristics of a stream. J . Soil Water Conserv. 42(2):111-114.

Falkenberg, C. 2006. Personal communication, Soilworks ${ }^{\circledR}$.

Frankenfeld, J . W., J . Elliott, R. E. Bently, and B. H. Sleight III. 1975. Toxic effects of oil discharged from ships. Linden, NJ : Exxon Research and Engineering Company.

Gebhart, D. L., T. A. Hale, and K. Michaels-Busch. 1996. Dust control material performance on unsurfaced roadways and tank trails. USAEC/ USACERL Technical Report. Champaign, IL: U.S. Army Construction Engineering Research Laboratories. http://aec.army.mil/usaec/technology/dustcontrol.pdf.

Guiney, P. D., D. M. Woltering, and M. J. Krzysztof. 1998. An environmental risk assessment profile of two synthetic polymers. Environ. Toxicol. Chem. 17(10):2122-2130.

Hatzinger P. B., and M. Alexander. 1995. Effect of aging of chemicals in soil on their biodegradability and extractability. Environ. Sci. Technol. 29:537- 545.

Heffner, K. 1997. Water quality effects of three dust-abatement compounds. Eng. Field Notes 29:35-43.

Hazardous Substance DataBank (HSDB). 2006. Hazardous substance databank. NIH. Bethesda, MD: U.S. National Library of Medicine. http://toxnet.nlm.nih.gov/.

Hughes, C. 2003. 7-Day survival and growth tests of dust suppression products EK-35 and EnviroKleen to the rainbow trout, Oncorhynchus mykiss, determined under static renewal conditions. Project report to Midwest Industrial Supply. Columbia, MI: ABC Laboratories, Inc. http://www.midwestind.com/uploads/RainbowTrout-910.pdf.

Kimball, C. E. 1997. Evaluating groundwater pollution susceptibility of dust suppressants and roadbed stabilizers: Case study of a petroleum-based product. Transportation Research Record 1589:64-69.

Lockhart, W. L., R. W. Danell, and D. A. J . Murray. 1987. Acute toxicity bioassays with petroleum products: influence of exposure conditions. In Oil in fresh water: Chemistry, biology, countermeasure technology, ed. J. H. Vandermeulen and S. R. Hrudey, 335-344. New York: Pergamon Press. 
Lohnes, R. A., and B. J . Coree. 2002. Determination and evaluation of alternate methods for managing and controlling highway-related dust. Iowa Highway Research Board Publication TR449. www.operationsresearch.dot.state.ia.us/reports/ reports_pdf/hr_and_tr/reports/tr449.pdf.

McMillen, S. J ., R. I. Magaw, and R. L. Carovillano, ed. 2001. Risk-based decision-making for assessing petroleum impacts at exploration and production sites. Tulsa, OK: U.S. Department of Energy and the Petroleum Environmental Research Forum.

Midwest Industrial Supply. 2001. When it comes to controlling dust, ultra-pure EnviroKleen is the answer to your prayers. http://www.midwestind.com/uploads/EKBro-437.pdf.

. 2002. Soil-Sement environmental data. Project report to Midwest Industrial Supply for EPA Environmental Technology Verification Program. http://www.midwestind.com/uploads/SSEnvDataShort-1474.pdf.

. 2005. MSDS for Soil-Sement dust and erosion control agent. Canton, $\mathrm{OH}$. http://www.midwestind.com/uploads/SSMSDS-1895.pdf.

. 2006. MSDS for EnviroKleen synthetic organic dust control agent. Canton, OH. http://www.midwestind.com/envirokleen-1.htm.

Moles, A., S. D. Rice, and S. Korn. 1979. Sensitivity of Alaskan freshwater and anadromous fishes to Prudhoe Bay crude oil and benzene. Trans. Am. Fish. Soc. 108(4): 408-414.

National Research Council (NRC). 2003. Bioavailability of contaminants in soils and sediments: Processes, tools, and applications. Washington, DC: National Academies Press.

National Toxicology Program (NTP). 1986. National toxicology program technical report series no. 310: Toxicology and carcinogenesis studies of marine diesel fuel and J P-5 navy fuel in mice (dermal studies). NTP/ NIGH publication number: 86-2566. Research Triangle Park, NC. http://ntpserver.niehs.nih.gov/ntp/htdocs/LT_rpts/tr310.pdf\#search=\%22Toxicology\%20and\% 20carcinogenesis\%20studies\%20of\%20marine\%20diesel\%20fuel\%20and\%20JP5\%20navy $\% 20$ fuel $\% 20$ in $\% 20$ mice $\% 20 \% 22$.

Palmer, J. T., T. V. Edgar, and A. P. Boresi. 1995. Strength and density modification of unpaved road soils due to chemical additives. MS thesis, Laramie, WY: University of Wyoming.

Pierce, J . T. 2006. Chronic reference exposure limit for polymer emulsion stabilizers (based on vinyl acetate), synthetic hydrocarbon stabilizers, and polysaccharide stabilizers (based on best professional judgment). Norfolk, VA: Navy Environmental Health Center.

Poirier, A., F. Baudin Laurencin, G. Bodennec, and C. Quentel. 1986. Experimental poisoning of the rainbow trout, (Salmo gairdneri) Richardson, by engine dieseloil: Mortalities, haematological changes, histology. Aquaculture 55(2):115-137. 
Price, R. A., T. R. Higgins, and B. L. Folsom, Jr. 1991. Vegetation as an agronomic method of dust control on helicopter training areas at Fort Rucker, AL. Miscellaneous Paper, EL-91-21. Vicksburg, MS: U.S. Army Engineer Waterways Experiment Station.

Rauch, A. F., L. E. Katz, and H. M. Liljestrand. 2003. Evaluation of nontraditional soil and aggregate stabilizers: A summary. University of Texas Center for Transportation Research, Project Summary Report 7-1993-S. www.utexas.edu/research/ctr/pdf_reports/7_1993_S.pdf.

Rice, S. D. 1973. Toxicity and avoidance tests with Prudhoe Bay oil and pink salmon fry. Proceedings, J oint Conference on Prevention and Control of Oil Spills, 13-15 March, Washington, DC. American Petroleum Institute.

Roald, S. O. 1977. Acute toxicity of ligninsulfonates on rainbow trout (Salmo gairdneri). Bull. Environ. Contam. Toxicol. 17(6):702-706.

Rushing, J . F., J . A. Harrison, and J . S. Tingle. 2005. Evaluation of application methods and products for mitigating dust for lines-of-communication and base camp operations. ERDC/ GSL TR-05-9. Vicksburg, MS: U.S. Army Engineer Research and Development Center.

Rushing, J . F., V. M. Moore, and J . S. Tingle. 2006. Evaluation of chemical dust palliatives for helipads. ERDC/ GSL TR-06-2. Vicksburg, MS: U.S. Army Engineer Research and Development Center.

Sanders, T. G., and J . Q. Addo. 1993. Effectiveness and environmental impact of road dust suppressants. MPC Report No. 94-28. Mountain Plains Consortium. www.mountain-plains.org/pubs/html/mpc-94-28.

Soilworks. 2004a. MSDS for Durasoil synthetic organic dust control agent. Gilbert, AZ: Soilworks, LLC. http://www.durasoil.com/MSDS.htm. . 2004b. MSDS for Surtac soil stabilizer dust control agent. Gilbert, AZ: Soilworks, LLC. . 2006a. Environmental data for Durasoil synthetic organic dust control agent. Gilbert, AZ: Soilworks, LLC. http://www.durasoil.com/Environmental_Data.htm. . 2006b. MSDS for Soiltac soil stabilizer and dust control agent. Gilbert, AZ: Soilworks, LLC. http://www.soilworks.com/MSDS.html.

. 2006c. Environmental data for Soiltac soil stabilizer and dust control agent. Gilbert, AZ: Soilworks, LLC. http://www.soilworks.com/Environmental_Data.html.

Tingle, J . S., C. A. Weiss, J. K. Newman, J . F. Peters, E. S. Berney, IV, S. Larson, and B. Tardy. 2004. Constitutive analyses of nontraditional stabilization additives. ERDC TR-04-5. Vicksburg, MS: U.S. Army Engineer Research and Development Center. www.stormingmedia.us/28/2819/A281924.html.

Tri-State Laboratories (TSL). 2002. Chemical analysis. In EnviroKleen environmental perspectives. Canton, OH: Midwest Industrial Supply. http://www.midwestind.com/uploads/EKEnvirPer-900.pdf. 
U.S. Army Environmental Center (USAEC). 2006. Dust: Controlling the problem. Training mission in sync with health, safety, and the environment. Aberdeen Proving Ground, MD: U.S. Army Environmental Center. http://aec.army.mil/usaec/technology/conservation01.html.

U.S. Environmental Protection Agency (USEPA). 1989. Risk assessment guidance for superfund, Volume I, Human health evaluation manual (Part A). EPA/ 540/ 189/ 002. Washington, DC: Office of Emergency and Remedial Response. . 1998. Guidelines for ecological risk assessment. EPA/630/R095/002F. Washington, DC: Risk Assessment Forum. . 2004. Potential environmental impacts of dust suppressants: Avoiding another times beach. EPA/600/R-04/ 031. Las Vegas, NV: University of Nevada. . 2006. Ecotox database. Duluth, MN: Office of Research and Development. http://cfpub.epa.gov/ecotox/.

U.S. Fish and Wildlife Service (USFWS). 1984. Acute toxicity rating scales. USFWS Research Information Bulletin No. 84-78. U.S. Fish and Wildlife Service.

Vandermeulen, J. H., and S. E. Hrudey. 1987. Oil in freshwater: Chemistry, biology, countermeasure technology. In Proceedings, Symposium on Oil Pollution in Freshwater, October 1984, Edmonton, Alberta, Canada. New York: Pergamon Press.

Washington Department of Ecology. 2003. Techniques for dust prevention and suppression. Washington Department of Ecology Publication Number 96-433. www.ecy.wa.gov/pubs/96433.pdf.

Zhordania, T. G., W. R. Morrison, W. T. Plass, and C. R. Stron. 1982. US/ USSRjoint studies on plastic films and soil stabilizers. Denver, CO: U.S. Department of the Interior. 


\section{Appendix A: Soiltac ${ }^{\circledR}$}

\section{Product information and identification}

- Manufacturer: Soilworks ${ }^{\circledR}$, LLC, 681 N. Monterey Street, Gilbert, AZ 85233-8318

- Telephone number: 800-545-5420

- Emergency telephone number: 800-545-5420

- Online information: http://www.soilworks.com/

\section{Composition}

Soiltac ${ }^{\circledR}$ is composed of vinyl acetate copolymer (50- 65 percent), water ( 50 - 35 percent), and vinyl acetate monomer ( $<0.5$ percent) (Soilworks 2006b).

Fluoride (0.2 mg/ L), acetone (110 mg/ L), and vinyl acetate (230 mg/ L) were detected in an undiluted sample. Several metals were detected including aluminum ( $1.2 \mathrm{mg} / \mathrm{L})$, arsenic $(0.6 \mathrm{mg} / \mathrm{L})$, barium $(0.4 \mathrm{mg} / \mathrm{L})$, boron (0.48 mg/ L), chromium (0.6 mg/ L), copper ( $0.9 \mathrm{mg} / \mathrm{L})$, iron $(0.9 \mathrm{mg} / \mathrm{L})$, manganese $(1.2 \mathrm{mg} / \mathrm{L})$, and zinc $(1.8 \mathrm{mg} / \mathrm{L})$. As reported, it was unclear if these were qualified data or represent method detection limits. However, it can be assumed these are detected compounds. No other metals were detected above $0.02 \mathrm{mg} / \mathrm{L}$. No volatile organics, organochlorine pesticides, polychlorinated biphenyls, chlorinated herbicides, carbamate pesticides, organophosphate pesticides, phenol, or cyanide were detected (Soilworks 2006c).

Acetic acid butyl ester (390 ppm), propanoic acid butyl ester (510 ppm), and vinyl acetate (375 ppm) were presented in the specified amounts. Chemical analysis was conducted by ERDC (2006) using purge-and-trap GC/MS.

\section{Physical and chemical information}

- Mixture

- Color: white, transparent when cured

- Odor: mild

- $\mathrm{pH}$ : 4.0-6.0

- Vapor pressure: $18.65 \mathrm{mmHg}$ at $21^{\circ} \mathrm{C}$ 
- Boiling point: $>100^{\circ} \mathrm{C}$

- Solubility in water: completely soluble

- Physical state: mobile liquid

- Specific gravity: 1.04 - 1.10 (Soilworks 2006b).

\section{Environmental fate and transport}

- Incompatibility: mineral acids and alkalis

- Stability: stable at ambient temperatures, coagulation may occur following freezing, thawing, or boiling

- Hazardous polymerization: will not occur (Soilworks 2006b).

No other information is available.

\section{Human health and toxicological data}

No known health hazards are reported on MSDS (Soilworks 2006b).

\section{Ecotoxicological data}

\section{Aquatic}

Fathead minnow (Pimephales promelas) had LC 50 values of $1,208 \mathrm{mg} / \mathrm{L}$ of undiluted product in a 96-hr acute toxicity test. Rainbow trout (Oncorhynchus mykiss) had $\mathrm{LC}_{50}$ values of $>1,000 \mathrm{mg} / \mathrm{L}$ of undiluted product in a 96-hr acute toxicity test. Water fleas, Daphnia magna and Ceriodaphnia dubia, had LC50 values of 608 and $154 \mathrm{mg} / \mathrm{L}$, respectively, in 48-hr acute toxicity tests. Green algae (Raphidocelus subcapitata) had LC50 values of $>1,000 \mathrm{mg} / \mathrm{L}$ of undiluted product in a 96-hr acute toxicity test (Soilworks 2006c).

\section{Terrestrial}

No plant or terrestrial data are available.

\section{Application and usage recommendations}

\section{Application}

Recommendations for application include pre-wetting the site with water at a rate of $100 \mathrm{ft}^{2} / \mathrm{gal}$. Various rates are recommended for helipads, runways, roadways, and general dust control (Table 1). Material should be diluted with water ranging from 1:4 to 1:35 (product:water). The 
manufacturer recommends applying the diluted product using spray nozzles in multiple coats and allowing the material to dry for 24 hours prior to area use.

\section{Personal protection}

- Eye protection: chemical safety glasses

- Hand protection: rubber or plastic gloves - the breakthrough time of the gloves must be greater than the intended use period

- Protective clothing: no specific recommendations

- Ventilation: maintain air concentrations in workspaces in accord with exposure standards on ingredients (Soilworks 2006b). 


\section{Appendix B: Soil-Sement ${ }^{\circledR}$}

\section{Product information and identification}

- Manufacturer: Midwest Industrial Supply, Inc., P.O. Box 8431, Canton, Ohio 44711

- Telephone number: (330) 456-3121

- Emergency telephone number: (330) 456-3121

- Online information: www.midwestind.com

\section{Composition}

Soil-Sement ${ }^{\circledR}$ is composed of acrylic and vinyl acetate polymer (5-50 percent) and water (95- 50 percent) (Midwest Industrial Supply 2005).

Aluminum (2.44 mg/ kg), barium (3.48 mg/ kg), chromium (0.075 mg/ kg), iron (1.64 mg/ kg), mercury ( $0.06 \mathrm{mg} / \mathrm{kg})$, nickel $(0.1 \mathrm{mg} / \mathrm{kg})$, zinc $(2.61 \mathrm{mg} / \mathrm{kg})$, and toluene $(1.555 \mathrm{mg} / \mathrm{kg})$ were detected in Soil Sement. No other volatile or semi-volatile organic compounds, metals, pesticides, or polycyclic aromatic hydrocarbons were detected (Midwest Industrial Supply 2001).

Chemical analysis by ERDC (2006) using gas chromatography with mass spectrometry revealed 1-butanol (1,500 mg/ L) and 2-ethyl-1-hexanol (7,200 mg/ L). Vinyl acetate was not detected (MDL 50 mg/ L).

\section{Physical and chemical information}

- Color: white

- Odor: acrylic odor

- $\mathrm{pH}: 4.0-9.5$

- Vapor pressure: $17 \mathrm{mmHg}$ at $20^{\circ} \mathrm{C}$

- Boiling point: $212^{\circ} \mathrm{C}$

- Solubility in water: dilutable

- Physical state: liquid

- Specific gravity: 1.01-1.15

- Flammability: nonflammable, dried polymer film will burn but will not support combustion (Midwest Industrial Supply 2005). 


\section{Environmental fate and transport}

- Stability: stable

- Incompatibility: no hazardous reactions are expected to occur under normal industrial conditions

- Hazardous decomposition: thermal decomposition in the presence of air may yield carbon monoxide and/ or carbon dioxide and water

- Hazardous polymerization: does not occur (Midwest Industrial Supply 2005).

No other information is available.

\section{Human health and toxicological data}

\section{Inhalation}

Vapor from stored, undiluted product can cause headache and nausea.

\section{Skin}

Stored undiluted, this product is slightly irritating to skin.

\section{Ingestion}

It may be irritating to the digestive tract.

\section{Ocular}

Causes slight irritation to the eyes (Midwest Industrial Supply 2005).

\section{Ecotoxicological data}

\section{Aquatic}

Soil-Sement ${ }^{\circledR}$ had no effect on the survival of Ceriodaphnia dubia in a $48-\mathrm{hr}$ acute toxicity test at concentrations up to $1,000 \mathrm{mg} / \mathrm{L}$. It had no effect on survival or reproduction of Ceriodaphnia dubia in a 7-day chronic toxicity test at concentrations up to $1,000 \mathrm{mg} / \mathrm{L}$.

Soil-Sement ${ }^{\circledR}$ had no effect on the survival of fathead minnow (Pimephales promelas) in a 96-hr acute toxicity test at concentrations up to $1,000 \mathrm{mg} / \mathrm{L}$. It had no effect on survival or growth of fathead minnow 
(Pimephales promelas) in a 7-day chronic toxicity test at concentrations up to $1,000 \mathrm{mg} / \mathrm{L}$.

The $\mathrm{LC}_{50}$ value for rainbow trout (Oncorhynchus mykiss) was 320 and $510 \mathrm{ml} / \mathrm{L}$ for $96-\mathrm{hr}$ and 7-day exposures, respectively. The chronic exposure concentration resulting in an effect in 50 percent of the test organism population ( $\mathrm{EC}_{50}$ value) for growth of rainbow trout (Oncorhynchus mykiss) was $540 \mathrm{ml} / \mathrm{L}$. The no-effect concentration for both acute and chronic studies was $700 \mathrm{ml} / \mathrm{L}$. The LC50 value for rainbow trout fry exposed for 96 hours was $720 \mathrm{ml} / \mathrm{L}$.

Soil-Sement ${ }^{\circledR}$ had no effect on the survival of goldfish (Carassius auratus) at 24,48 , or 72 hours in an acute toxicity test at concentrations up to $12,500 \mathrm{mg} / \mathrm{L}$.

Soil-Sement ${ }^{\circledR}$ had no effect on the survival of Americamysis bahia in a 96-hr acute toxicity test at concentrations up to $1,000 \mathrm{mg} / \mathrm{L}$. It had no effect on the survival, growth, or reproduction of Americamysis bahia in a 7-day chronic toxicity test at concentrations up to $1,000 \mathrm{mg} / \mathrm{L}$.

Data are from various laboratory reports and summarized in Midwest Industrial Supply $(2002,2005)$.

\section{Terrestrial}

No terrestrial ecotoxicology data are available.

\section{Application and usage recommendations}

\section{Application rates}

Manufacturer recommendations and rates are provided for military applications including helipads, runways, roadways, and tank tracked vehicles (Table 1). Material should be diluted with water 1:9 (product:water). The manufacturer recommends applying the diluted product using spray nozzles using 2 to 3 passes and allowing travel immediately.

\section{Personal protection}

- Respiratory protection: none required if good ventilation is maintained; mechanical exhaust at point of contaminant is recommended 
- Eye protection: chemical splash goggles recommended

- Hand protection: impervious gloves recommended

- Other: under normal handling conditions, the risk of exposure to residual monomer is negligible (Midwest Industrial Supply 2005). 


\section{Appendix C: Envirotac II}

\section{Product information and identification}

- Manufacturer: Environmental Products and Applications, Inc., 73-710 Fred Waring Drive, Suite 220, Palm Desert, CA 92260

- Telephone number: (760) 779-1814

- Online information: www.wenvirotac.com

\section{Composition}

Envirotac II is composed of acrylic polymer (39- 43 percent), water (35-50 percent), aqua ammonia ( $<1.0$ percent), and individual residual monomers ( $<0.1$ percent) (EPI 2000).

No semivolatile organic compounds were detected (MDL 1-100 mg/ L). Barium $(0.13 \mathrm{mg} / \mathrm{L})$ and mercury $(0.03 \mathrm{mg} / \mathrm{L})$ were detected. No other metals were detected (MDL 0.01 - 0.3 mg/ L) (EPI 2001).

Chemical analysis by ERDC (2006) using gas chromatography mass spectrometry detection revealed the presence of n-butyl ether (690 mg/ L). Vinyl acetate was not detected (MDL $5 \mathrm{mg} / \mathrm{L}$ ).

\section{Physical and chemical information}

- Color: white

- Odor: ammonia odor

- pH: 5.0 - 9.5

- Vapor pressure: $17 \mathrm{mmHg}$ at $20^{\circ} \mathrm{C}$

- Boiling point: $100^{\circ} \mathrm{C}$

- Melting point: $0^{\circ} \mathrm{C}$

- Solubility in water: dilatable

- Physical state: liquid

- Specific gravity: 1.0-1.2

- Viscosity: 1500 CPS maximum

- Flashpoint: noncombustible (EPI 2000). 


\section{Environmental fate and transport}

- Stability: stable, thermal decomposition above $177^{\circ} \mathrm{C} / 350^{\circ} \mathrm{F}$ resulting in acrylic monomers

- Incompatibility: no known incompatibilities

- Hazardous decomposition: thermal decomposition may yield acrylic monomers

- Hazardous polymerization: product will not undergo polymerization (EPI 2000).

No other information is available.

\section{Human health and toxicological data}

\section{Inhalation}

Inhalation of vapor or mist can cause headache, nausea, irritation of nose, throat, and lungs.

\section{Skin}

Prolonged or repeated contact can cause slight skin irritation. Dermal $\mathrm{LD}_{50}$ is $>5,000 \mathrm{mg} / \mathrm{kg}$ in rabbits. It is practically non-irrupting in tests using rabbits.

\section{Ingestion}

Oral toxicity (acute) $\mathrm{LD}_{50}$ for rats was $>5,000 \mathrm{mg} / \mathrm{kg}$.

\section{Ocular}

Direct contact with material can cause slight irritation. Inconsequential eye irritation was produced in tests using rabbits (EPI 2000).

\section{Ecotoxicological data}

No toxicity was observed in a 4-day study using juvenile fathead minnows (Pimephales promelas) (35 mm, $0.44 \mathrm{~g}$ ) at concentrations up to $750 \mathrm{mg} / \mathrm{L}$ (EPI 2001).

No terrestrial ecotoxicology data exist. 


\section{Application and usage recommendations}

\section{Application rates}

Various rates are recommended for helipads, runways, roadways, and general dust control (Table 1). Material should be diluted with water ranging from 1:4 to 1:12 (product:water). The manufacturer recommends applying the diluted product using spray nozzles and allowing the material to dry for 12 to 24 hours prior to area use.

\section{Personal protection}

- Respiratory protection: A respiratory protection program meeting OSHA and American National Standards Institute (ANSI) standards must be followed. If airborne concentrations are up to 10 times the exposure limit, a half-mask air purifying respirator equipped with ammonia/methylamine cartridges and N95 filters should be used. Local exhaust ventilation with a minimum capture velocity of $100 \mathrm{ft} / \mathrm{min}$ at the point of vapor evolution should also be used.

- Eye protection: Safety glasses with side shields must be used. Eye protection worn must be compatible with respiratory protection system.

- Hand protection: Gloves other than chemically resistant materials may not provide adequate protection (neoprene). 


\section{Appendix D: EnviroKleen ${ }^{\circledR}$}

\section{Product information and identification}

- Manufacturer: Midwest Industrial Supply, Inc., P.O. Box 8431, Canton, Ohio 44711

- Telephone number: (330) 456-3121

- Emergency telephone number: (330) 456-3121

- Online information: www.midwestind.com

\section{Composition}

EnviroKleen ${ }^{\circledR}$ is a severely hydrotreated, hydrocracked, hydroisomerized, and high viscosity synthetic iso-alkane (percent composition unavailable) (Midwest Industrial Supply 2006).

Metals analysis revealed aluminum ( $1.0 \mathrm{mg} / \mathrm{kg})$, iron $(25.0 \mathrm{mg} / \mathrm{kg})$, manganese $(0.12 \mathrm{mg} / \mathrm{kg})$, and zinc $(0.137 \mathrm{mg} / \mathrm{kg})$. No semi-volatiles (MDL 0.112- $0.575 \mathrm{mg} / \mathrm{L}$ ), volatiles (MDL 2.14- $4.28 \mathrm{mg} / \mathrm{L}$ ), or pesticides (MDL 0.03- $0.145 \mathrm{mg} / \mathrm{L}$ ) were detected. Sulphur content is below $1 \mathrm{mg} / \mathrm{L}$ (TSL 2002).

Chemical analysis by ERDC (2006) using gas chromatography with flame ionization detection revealed a carbon range from C18 thru C28.

\section{Physical and chemical information}

- Color: clear

- Odor: none

- $\mathrm{pH}: \mathrm{N} / \mathrm{A}$ not an aqueous solution

- Vapor pressure: negligible at $20^{\circ} \mathrm{C}$

- Boiling point: $>316^{\circ} \mathrm{C}$

- Solubility in water: insoluble

- Physical state: viscous liquid

- Specific gravity: 0.83

- Pour point: $-36^{\circ} \mathrm{C}$

- Flammability: nonflammable, but will burn on prolonged exposure to flame or high temperature

- Flashpoint: $>170^{\circ} \mathrm{C}$

- Autoignite temperature: $351^{\circ} \mathrm{C}$ (Midwest Industrial Supply 2006). 


\section{Environmental fate and transport}

- Stability: stable under normal handling conditions, stored at temps between $-40^{\circ} \mathrm{F}$ and $+180^{\circ} \mathrm{F}$

- Incompatibility: strong organic oxidizing materials

- Hazardous decomposition: carbon monoxide and/ or carbon dioxide, smoke, hydrocarbons, and irritating fumes

- Hazardous polymerization: does not occur under normal industrial conditions (Midwest Industrial Supply 2006).

Biodegradability by OECD method 301B is 60 percent. The synthetic isoalkane portion has the potential for degradation by hydroxyl radicals in the troposphere under the influence of sunlight and by bacteria in soil water. Potential for food chain concentration is low (Midwest Industrial Supply 2001).

No other information is available.

\section{Human health and toxicological data}

\section{Inhalation}

Inhalation is highly unlikely. However, prolonged or repeated inhalation of fumes or mists may cause irritation to the respiratory tract. Product deposits in lungs may lead to fibrosis and reduced pulmonary function. May be irritating to breathing passages upon excessive heating. Otherwise this product is essentially non-hazardous. Mist 8-hr threshold limit value/ time weighted average (TLV-TWA) $=5 \mathrm{mg} / \mathrm{m}^{3}(\mathrm{ACGIH})$. Inhalation toxicity (acute) EPA/TSCA 40 CFI 178.1150 - Non-toxic LD $50>2,500 \mathrm{mg} / \mathrm{m}^{3}$ (Midwest Industrial Supply 2001, 2006).

\section{Skin}

Prolonged or repeated contact may cause skin irritation, dermatitis, or oil acne. Dermal toxicity (acute) EPA/ TSCA 40 CFR 178.1100 - Non-toxic $\mathrm{LD}_{50}>2,000 \mathrm{mg} / \mathrm{kg}$ (skin/rabbit). EnviroKleen ${ }^{\circledR}$ is not a skin irritant by acute dermal irritation/ corrosion method by EPA/ TSCA 40 CFR 178.4470 (Midwest Industrial Supply 2001, 2006). 


\section{Ingestion}

EnviroKleen ${ }^{\circledR}$ is relatively non-toxic to the digestive tract. Oral toxicity (acute) EPA/TSCA 40 CFR 178.1175 - Practically non-toxic LD $\mathrm{LD}_{50}>$ $5,000 \mathrm{mg} / \mathrm{kg}$ (oral/ rat) (Midwest Industrial Supply 2001, 2006).

\section{Ocular}

EnviroKleen ${ }^{\circledR}$ is not an eye irritant by acute eye irritation/ corrosion method EPA/TSCA 40 CFR 178.4500 (Midwest Industrial Supply 2001).

\section{Carcinogenicity}

ACGIH (mists) - Based on available human studies, exposure to product mist alone has not demonstrated to cause human effects at levels below $5 \mathrm{mg} / \mathrm{m}^{3}$.

IARC - IARC group 3; cannot be classified as to carcinogenicity to humans. A mutagenicity by modified Ames test resulted in negative (Midwest Industrial Supply 2001, 2006).

\section{Ecotoxicological data}

\section{Aquatic}

No acute or chronic toxicity was observed in studies using three different species. A Ceriodaphnia dubia, 48-hr acute study provided no effect on survival at 1,000 mg/ L. In the fathead minnow and Americamysis bahia, a 96-hr acute study produced no effect on survival at 1,000 mg/ L. In Ceriodaphnia dubia, a 7-day chronic study produced no effect on survival or reproduction at $1,000 \mathrm{mg} / \mathrm{L}$. A fathead minnow 7-day chronic study provided no effect on survival or weight at $1,000 \mathrm{mg} / \mathrm{L}$. An Americamysis bahia, 7-day chronic study produced no effect on survival, reproduction, or weight at 1,000 mg/ L (ABC Laboratories 2002).

No acute toxicity was reported in two species. In rainbow trout (Oncorhynchus mykiss), a 96-hr acute study provided no effect on survival at $500,000 \mathrm{mg} / \mathrm{L}$. In Daphnia magna, a 96-hr acute study provided no effect on survival at 500,000 mg/ L. No toxicity was observed using Microtox luminescent bacteria bioassay (Midwest Industrial Supply 2001). 
No acute toxicity (survival or growth) was reported in rainbow trout (Oncorhynchus mykiss) in a 7-day static exposure at concentrations up to 1,000 mg/ L (Hughes 2003).

\section{Terrestrial}

No information is available.

\section{Application and usage recommendations}

\section{Application rates}

Manufacturer recommendations and rates are provided for military applications including helipads, runways, roadways, and tank tracked vehicles (Table 1). Material should not be diluted. The manufacturer recommends that EnviroKleen ${ }^{\circledR}$ may be traveled upon and helicopter landing allowed immediately. For jet aircraft, the applicator should allow up to 3 hours for incorporation into soil.

\section{Personal protection}

- Eye protection: chemical splash goggles recommended

- Hand protection: for casual contact, PVC gloves are suitable, for prolonged contact, use neoprene or nitrile gloves

- Protective clothing: none required if good ventilation is maintained. If mist is generated by heating or spraying, a NIOSH approved organic respirator with a mist filter is recommended (Midwest Industrial Supply 2006). 


\section{Appendix E: Durasoil ${ }^{\circledR}$}

\section{Product information and identification}

- Manufacturer: Soilworks ${ }^{\circledR}$, LLC, 681 N. Monterey Street, Gilbert, AZ 85233-8318

- Telephone number: 800-545-5420

- Emergency telephone number: 800-545-5420

- Online information: www.soilworks.com

\section{Composition}

Durasoil ${ }^{\circledR}$ is composed of severely hydrotreated, branched alkanes and alkylated saturated ring compounds (Soilworks 2004a).

Chemical analysis by ERDC (2006) using gas chromatography with flame ionization detection revealed a carbon range from C22 thru C30.

No pesticides were detected from a range of $0.01 \mathrm{mg} / \mathrm{L}$ to $10 \mathrm{mg} / \mathrm{L}$ (detection limit). No metals were detected from a range of $0.5 \mu \mathrm{g} / \mathrm{L}$ to $0.5 \mathrm{mg} / \mathrm{L}$. No volatiles detected from a range of 1 to $75 \mathrm{mg} / \mathrm{L}$. Total extractable organics were not detected due to elevated reporting limits (1,000 mg/ L) (Soilworks 2006a).

\section{Physical and chemical information}

- Color: clear

- Odor: odorless

- $\mathrm{pH}: \mathrm{N} / \mathrm{A}$ not an aqueous solution

- Vapor pressure: $<1 \mathrm{mmHg}$

- Boiling point: $>260^{\circ} \mathrm{C}$

- Solubility in water: insoluble

- Physical state: viscous liquid

- Specific gravity: 0.845-865

- Pour point: $-5^{\circ} \mathrm{C}$

- Flashpoint: $>149^{\circ} \mathrm{C}$ (Soilworks 2004a). 


\section{Environmental fate and transport}

- Stability: stable

- Incompatibility: may react with strong organic oxidizing agents

- Hazardous decomposition: carbon monoxide, carbon dioxide, and other oxides that may be generated as products of combustion

- Hazardous polymerization: will not occur (Soilworks 2004a).

No other information is available.

\section{Human health and toxicological data}

No toxicological data are available (Soilworks 2006a).

\section{Ecotoxicological data}

\section{Aquatic toxicity}

No effects on survival were observed in 4-day old rainbow trout (Oncorhynchus mykiss), juvenile fathead minnow (Pimephales promela), and 1- to 5-day old mysid shrimp (Americamysis bahia) exposed to up to 10,000 mg/ L Durasoil ${ }^{\circledR}$ in a 96-hr toxicity test (BES 2005a).

No effects on survival were observed in (unknown age) fathead minnow (Pimephales promela) exposed up to $750 \mathrm{mg} / \mathrm{L}$ Durasoil ${ }^{\circledR}$ in a 96-hr toxicity test (BES 2005b).

Significant mortality in the water flea (Daphnia magna) was observed at concentrations as low as $1 \mathrm{mg} / \mathrm{L}$ in a 96-hr toxicity bioassay (BES 2005c).

Chronic toxicity (survival and growth) was not observed in a 7-day toxicity test using larval fathead minnow (Pimephales promela) at concentrations up to $10,000 \mathrm{mg} / \mathrm{L}$. Chronic toxicity (algal growth) was not observed in a 96-hr toxicity test using green algae (Selenastrum capricornutum) at concentrations up to $10,000 \mathrm{mg} / \mathrm{L}$. Significant toxicity (survival and reproduction) of Daphnia magna was observed. The $\mathrm{LC}_{50}$ value was $9.18 \mathrm{mg} / \mathrm{L}$ (no variance reported). The $\mathrm{IC}_{50}$ value for reproduction was $9.07 \mathrm{mg} / \mathrm{L}$ (no variance reported) (BES 2005d).

Sediment toxicity was assessed using a 10-day Hyalella azteca amphipod bioassay. Briefly, Durasoil ${ }^{\circledR}$ was applied to soil at different rates ( $1 \mathrm{gal} / 50 \mathrm{ft}^{2}, 1 \mathrm{gal} / 35 \mathrm{ft}^{2}$, and $1 \mathrm{gal} / 20 \mathrm{ft}^{2}$ ), the soil wetted, and toxicity test 
conducted. This is a conservative estimate because it is assumed that the coated soil is washed into the water body. Using this approach, significant mortality in amphipods was observed at $1 \mathrm{gal} / 35 \mathrm{ft}^{2}$ and $1 \mathrm{gal} / 20 \mathrm{ft}^{2}$ (BES 2005e).

\section{Terrestrial toxicity}

No effect on the earthworm (Eisenia fetida) was observed following 14-day exposures to Durasoil ${ }^{\circledR}$ at $1 \mathrm{gal} / 50 \mathrm{ft}^{2}, 1 \mathrm{gal} / 35 \mathrm{ft}^{2}$, and $1 \mathrm{gal} / 20 \mathrm{ft}^{2}$ treatments (BES 2005f).

\section{Application and usage recommendations}

\section{Application rates}

Various rates are recommended for helipads, runways, roadways, and general dust control (Table 1). Material should not be diluted.

\section{Personal protection}

- Eye protection: Eye protection is not required under conditions of normal use. If material is handled such that it could be splashed into eyes, wear splash-proof safety goggles.

- Hand protection: No skin protection is required for single, short duration exposures. For prolonged or repeated exposures, use impervious synthetic rubber (boots, gloves, aprons, etc.) over parts of the body subject to exposure (Nitrile recommended).

- Protective clothing: Launder soiled clothes.

- Ventilation: This is not required under normal conditions in a wellventilated workspace. An organic vapor respirator NIOSH approved for organic vapors is recommended under emergency conditions (Soilworks 2004a). 


\section{Appendix F: Surtac ${ }^{\circledR}$}

\section{Product information and identification}

- Manufacturer: Soilworks ${ }^{\circledR}$, LLC, 681 N. Monterey Street, Gilbert, AZ 85233-8318

- Telephone number: 800-545-5420

- Emergency telephone number: 800-545-5420

- Online information: www.soilworks.com

\section{Composition}

Surtac ${ }^{\circledR}$ is composed of a mixture of polyols and partially hydrogenated heterocyclics, water (32-35 percent), and other proprietary ingredients (Soilworks 2004b).

Chemical analysis by ERDC (2006) using gas chromatography mass spectrometry revealed no quantifiable peaks.

\section{Physical and chemical information}

- Color: paleyellow

- Odor: sweet

- $\mathrm{pH}: 5.5-7.0$

- Vapor pressure: no data

- Boiling point: $105^{\circ} \mathrm{C}$

- Melting point: $170^{\circ} \mathrm{C}$

- Solubility in water: soluble

- Physical state: viscous liquid emulsion

- Specific gravity: 1.37 (Soilworks 2004b).

\section{Environmental fate and transport}

- Stability: stable

- Incompatibility: may react with strong organic oxidizing agents

- Hazardous decomposition: carbon monoxide, carbon dioxide, and other oxides that may be generated as products of combustion

- Hazardous polymerization: will not occur (Soilworks 2004_).

No other information is available. 


\section{Human health and toxicological data}

\section{Dermal}

Prolonged or repeated exposure and contact with skin may cause irritation.

\section{Carcinogenicity}

None of the components present in this material at concentrations equal to or greater than 0.1 percent are listed by IARC, National Toxicology Program, OSHA, or ACGIH as a carcinogen.

Ingestion

Ingestion may destabilize people with diabetes (Soilworks 2004b).

\section{Ecotoxicological data}

No ecotoxicological data are available.

\section{Application and usage recommendations}

\section{Application rates}

Limited information is available for application rates and methods. However, application rates (Table 1) were provided by the manufacturer for application to helipads for dust control.

\section{Personal protection}

- Eye protection: Eye protection is not required under normal use.

- Hand protection: No skin protection is required for single, short duration exposures. For prolonged or repeated exposures, use impervious synthetic rubber (boots, gloves, aprons, etc.) over parts of the body subject to exposure (Nitrile recommended).

- Protective clothing: Launder soiled clothes.

- Ventilation: This is not required under normal conditions in a wellventilated workspace (Soilworks 200b4). 


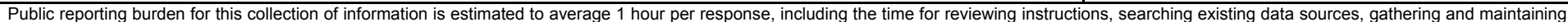

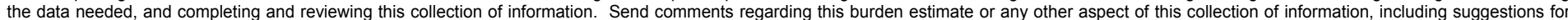

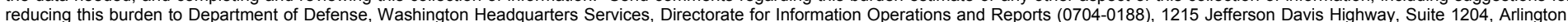

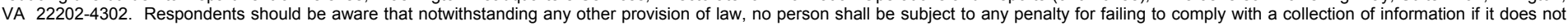
display a currently valid OMB control number. PLEASE DO NOT RETURN YOUR FORM TO THE ABOVE ADDRESS.
1. REPORT DATE (DD-MM-YYYY) August 2007

$$
\text { Final report }
$$

\section{TITLE AND SUBTITLE}

Environmental Evaluation of Dust Stabilizer Products
3. DATES COVERED (From - To)

\section{5a. CONTRACT NUMBER}

5b. GRANT NUMBER

5c. PROGRAM ELEMENT NUMBER

5d. PROJECT NUMBER

5e. TASK NUMBER

\section{5f. WORK UNIT NUMBER}

8. PERFORMING ORGANIZATION REPORT NUMBER

ERDC/EL TR-07-13

U.S. Army Engineer Research and Development Center

3909 Halls Ferry Road, Vicksburg, MS 39180-6199

Navy Environmental Health Center

620 JP Jones Circle \#1100, Portsmouth, VA 23708

9. SPONSORING / MONITORING AGENCY NAME(S) AND ADDRESS(ES)

U.S. Army Corps of Engineers

Washington, DC 20314-1000

10. SPONSOR/MONITOR'S ACRONYM(S)

11. SPONSOR/MONITOR'S REPORT NUMBER(S)

\section{DISTRIBUTION / AVAILABILITY STATEMENT}

Approved for public release; distribution is unlimited.

\section{SUPPLEMENTARY NOTES}

\section{ABSTRACT}

Personnel of the U.S. Army Engineer Research and Development Center (ERDC), Vicksburg, MS, and Navy Environmental Health Center (NEHC), Portsmouth, VA, evaluated the environmental fate and effects of six commercially available dust stabilizer products. As part of the evaluation, a relative risk comparison was made of the six materials to other materials that have been used historically to control dusts (i.e., diesel, crude oil, fuel oil). Data for this evaluation were obtained primarily through literature review, communication with the manufacturers of the products, and through some limited analytical chemistry. Data gaps and uncertainties were also identified and described. Conclusions were derived from the results of the evaluation, with each stabilizer group presented separately along with general conclusions applicable to all stabilizers studied.

\section{SUBJECT TERMS}

Dust stabilizer

Exposure

16. SECURITY CLASSIFICATION OF:

\section{a. REPORT}

UNCLASSIFIED
Fate

Risk assessment

b. ABSTRACT
UNCLASSIFIED

c. THIS PAGE

UNCLASSIFIED
Toxicity

\begin{tabular}{l|c|}
$\begin{array}{l}\text { 17. LIMITATION } \\
\text { OF ABSTRACT }\end{array}$ & $\begin{array}{c}\text { 18. NUMBER } \\
\text { OF PAGES }\end{array}$ \\
& 68 \\
&
\end{tabular}

19a. NAME OF RESPONSIBLE PERSON

19b. TELEPHONE NUMBER (include area code) 